\title{
On the Importance of a Procedurally Fair Organizational Climate for Openness to Change in Law Enforcement
}

\author{
Laure Brimbal*1, Ben Bradford ${ }^{2}$, Jonathan Jackson ${ }^{3}$, Maria Hartwig ${ }^{4}$ and Emily Joseph ${ }^{4}$ \\ ${ }^{1}$ Department of Criminal Justice, Texas State University, USA \\ ${ }^{2}$ Jill Dando Institute of Security and Crime Science, University College London, UK \\ ${ }^{3}$ Department of Methodology, London School of Economics \& Political Science, UK, and University of Sydney \\ Law School, Australia \\ ${ }^{4}$ Department of Psychology, John Jay College of Criminal Justice, City University New York, New York City, \\ USA
}

*Laure Brimbal, Department of Criminal Justice, Texas State University, San Marcos, USA

laure.brimbal@gmail.com

\begin{abstract}
Objectives
Drawing on recent work in policing and organizational psychology, we examined factors related to openness to organizational change and to adopting evidence-based interview techniques among law enforcement investigators.

\section{Hypotheses}

We hypothesized that a procedurally fair organizational climate would predict outcomes tied to organizational change, mediated by organizational identification and perceived legitimacy. We also predicted that procedural justice factors would be stronger predictors than outcome-oriented factors (i.e., rewards and sanctions).
\end{abstract}

\section{Methods}

Study 1 surveyed law enforcement investigators $(N=711)$ about their attitudes towards and behaviors within their organization (i.e., perceived procedural fairness of one's organization, identification, legitimacy, compliance, empowerment, and extra-role behavior). Study 2 conceptually extended this survey to interviewers $(N=71)$ trained in a new, evidence-based interviewing approach adding likelihood of future use of the novel interviewing approach as an outcome.

\section{Results}

In Study 1, the more investigators thought their organization had a procedurally fair climate, the more they identified with the organization and perceived it as legitimate. Framing compliance, empowerment and extra-role behavior as associated with openness to change, we found that legitimacy predicted compliance and tendency toward extra-role behavior (i.e., going "above and beyond"), while level of identification predicted feelings of empowerment and extra-role behavior. Study 2, partially replicated findings from Study 1, and found that motivation to attend the training also predicted likelihood of future use.

\section{Conclusions}

These studies highlight the value of a procedurally just organizational climate framework in understanding law enforcement interrogators' propensity towards implementing new evidence-based interrogation techniques.

Keywords: Organization climate, Procedural justice, Evidence-based interrogation, Police culture, Programs of change.

\section{Public Significance Statement}

Our findings suggest that organizations with a procedurally fair organizational climate will be most successful at implementing programs of change. In particular, procedural fairness within law enforcement organizations is important to consider when implementing programs of change, especially evidence-based training. 
Police organizations in the United States and beyond are increasingly being asked to become more 'evidence-based'. Ever since Sherman's (1998) call for the inclusion of scientific evidence on 'what works' into decisions about police powers and tactics, the attention of police managers - and front-line staff - has been directed more and more towards what academic research has to say about their practice (Weisburd \& Neyroud 2011). By focusing on the accrual of evidence from high-quality research studies and evaluations, police organizations should be able to use scarce resources more effectively, produce better outcomes, and avoid some of the pitfalls associated with outdated or counterproductive tactics.

Yet, the acceptance and implementation of evidence-based policing within police departments has been patchy at best (Lum 2009; Lum et al., 2012; Telep \& Lum, 2014). While the scientific knowledge base surrounding policing has grown substantially in recent decades, Sherman (2013) argues that use of this knowledge remains far less impressive. Police leaders and managers may accept and embrace evidence-based policing (Mastrofski, 2014), but this seems to have not yet percolated down to the rank-and-file, who seemingly remain convinced of the value of on-the-job practical and craft knowledge over scientific evidence and 'expert opinion' (Lum et al., 2012).

One key area of policing where research and practice have long been in a state of opposition is interviewing practices. The scientific consensus is that current interrogation practice, both in criminal justice and human intelligence-gathering contexts, would benefit from major overhaul (Hartwig et al., 2014; Kassin et al., 2010; Meissner et al., 2014). Yet, despite the amount of research on the topic of interviewing, there has to date been no systematic effort to understand how to effectively implement evidence-based interview interrogation techniques. Across two studies, we sought to apply wellestablished bodies of work in other domains (e.g., change management, procedurally just organizational climate) to identify the predictors of openness and resistance to change in a large sample of law enforcement professionals (Study 1) and tested whether these factors indeed predict intent to use evidence-based interview techniques after being trained in them (Study 2).

\section{Barriers to Change Programs in Law Enforcement}

The literature on the reception of evidence-based policing intersects with a larger body of work on change within police organizations. Research over many years, and in many different contexts, has found that resistance to new developments and programs of change is widespread, particularly when reforms diverge significantly from accepted operational norms and/or stem from sources outside the police (e.g. academics or policy entrepreneurs) - which is, as Bayley (2008) notes, often the case.

Explanations for this resistance often revolve around three aspects of law enforcement work. First, there is the long list of problems associated with "police culture"-not only cynicism but also pessimism, conservatism, action-orientation and an inward-looking mentality (Foster, 2003; Loftus, 2010; Reiner, 2010) - many of which seem a priori likely to inhibit processes of change. Second, there is the frequently "top-down" nature of reform, which is usually initiated at behest of senior management but must be implemented by the front-line (Gau \& Gaines, 2012). Police officers can be cynical and suspicious not only about outsiders, but also their superiors (Reiner, 2010), making them unwilling to implement change programs they perceive as being "handed down from on high" (MacQueen \& Bradford, 2017). Third, street-level police officers classically operate in a low visibility environment without managerial oversight, and moreover are empowered in many jurisdictions to use their discretion when deciding on what to do, to whom, and why. In sum, it is hardly surprising that the academic and policy literature is replete with accounts of the differential uptake, troubled delivery, and indeed outright failure of change programs (Boba \& Crank, 2008; Cordner, 2000; Skogan, 2008). These problems create a significant challenge for police leaders, and the broader policy and academic communities that now surround policing, who seek to promote evidence-based practice.

\section{Overcoming Resistance to Change in Law Enforcement}

Willis and Mastrofski (2014, pp. 322-323) outline three possible routes to overcoming resistance in law enforcement. The first, replacing reluctant or oppositional front-line officers with new recruits who accept the value of evidence-based practice, is dismissed for obvious reasons as unfeasible in the short to medium term. The second route, training and supervision to 'indoctrinate' officers in the new way of working, "so that they appreciate and accept that evidence-based policing should be the driving force in their decision-making" (p. 323), is considered problematic for all the reasons outlined previously. The 
third is the co-option of frontline staff into the project by drawing on their craft-based skills and incorporating on-the-job knowledge into the wider evidenced-based policing program.

Our focus in this paper is on the second route-we consider the idea that training and supervision could, in fact, work if it occurs within a procedurally just organizational climate. Leaving aside the notion of 'indoctrination', which is a big topic that would need a proper and lengthy discussion, we explore what it is about the relationship between police- and law-enforcement officials and the organizations they work for that might inhibit, or promote, the formers receptivity to training and development premised on evidence-based principles.

\section{Using Work on Procedurally Fair Organizational Climate to Overcome Resistance to Change}

An emerging body of work has suggested that the best way to promote change within law enforcement agencies is by changing the ways officers relate to their organization (Trinkner et al., 2016; Tyler et al., 2007). Specifically, scholars have suggested that by adhering to principles of procedural justice within law enforcement agencies, senior managers and supervisors can encourage front-line staff to adhere to rules and regulations (Bradford et al., 2014a; Haas et al., 2015; Tyler et al., 2007), take on new ways of working and extra-role activities (Gau \& Gaines, 2012; Trinkner et al., 2016), and modulate their attitudes towards those they police (Bradford \& Quinton, 2014; Myhill \& Bradford, 2013; Trinkner et al., 2016).

The literature on procedural justice within organizations places this relationship center stage. It claims that the ways people conceive of their employer, and their place within the organization, is central to the way they behave in work-related contexts. It says that people working within organizations are sensitive to the way their superiors wield power and authority: Employees attend closely to whether supervisors and managers make decisions in an equitable, open and transparent manner, behave in an unbiased fashion, and treat staff members with dignity and respect. In turn, such behaviors promote a sense among staff members that their superiors are trustworthy, that they are supported by their organization, that they have a stake within it, and that the organization is legitimate (Colquitt et al., 2001; Tyler, 2011; Tyler \& Blader, 2003). Moreover, feelings of trust, support, inclusion, and legitimacy promote, in turn, compliance, cooperation, extra-role activities and "organizational citizenship behaviors." Notably, the association between these "internal" justice perceptions and organizational outcomes appears stronger and more consistent than the association between instrumental concerns and outcomes. While promises of reward and threats of sanction do seem to motivate compliance and other behaviors within organizations, studies have consistently found that effect sizes tend to be smaller than those associated with procedural justice concerns (Blader \& Tyler, 2009; Bradford et al., 2014a; Tyler \& Blader, 2000), organizational commitment (Qureshi et al., 2016; for review, see Riketta, 2004), and legitimacy (Bradford \& Quinton, 2014; Skogan \& Frydl, 2004; Treviño et al., 2014).

"Organizational citizenship behaviors" such as compliance with policies and procedures, feeling empowered to make decisions in the workplace, and extra-role acts such as volunteering for overtime are all desired behaviors in frontline law enforcement officers. These are also essential to successfully implement a program of change, especially if it is in contrast with current workforce practices. If officers are willing to comply with novel orders, go 'above and beyond', and trust themselves to make the proper decision about implementation, it is more likely that they will be more open to change, and more willing to implement change programs, when an organization implements such a process. We therefore frame compliance, empowerment and extra-role behavior as "openness to change."

\section{Psychological Mechanism of Promoting Change}

Which psychological mechanisms link the experience of procedural justice within organizations with the positive openness to change outcomes of compliance, empowerment and extra-role behavior? Two, in particular, concern us here. The first of these mechanisms is identity, with the experience of procedural justice strengthening identification with the organization (Bradford et al., 2014a; Bradford \& Quinton, 2014; Tyler \& Blader, 2003). When people feel fairly treated by managers and supervisors, they are more likely to feel proud of their organization and their role within it, and that they are accorded a high status by co-workers and superiors. In turn, identification and the associated feeling of self-worth linked to such experiences (De Cremer \& Tyler, 2005) activate a sense of duty toward the organization and a merging sense of self with the group and internalization of organizational goals and values 
(Ashforth \& Mael, 1989; Tyler \& Blader, 2000). People who identify strongly with an organization follow its norms and rules because they have adopted (and internalized) these as their own. Indeed, studies suggest that positive forms of identification with the organization can promote commitment to compliance with organizational goals, "citizenship behaviors," and new and changing organizational priorities. Organizational identification may even reduce the effect of cynical cultural adaptations to programs of change (e.g., Bradford \& Quinton, 2014).

The second mechanism that is thought to link procedural justice and the outcomes outlined earlier is legitimacy. On this account, feeling fairly treated within and by an organization promotes a sense that its structure of authority is legitimate and therefore worthy of obedience (Murphy et al., 2016; Tyler \& Jackson, 2013). In particular, procedurally fair processes and interactions indicate to people working in an organization that power within it is wielded in a normatively justifiable manner- that managers and supervisors "do the right things for the right reasons" (Suchman, 1995; Jackson \& Bradford, 2019). This sense of normative alignment between the power-holder's values and those of subordinates motivates a feeling that the orders and instructions of power-holders within the organization should be obeyed (Jackson et al., 2012; Tyler et al., 2007; Trinkner et al., 2018) and that police are justified in using force and employing new technologies (Tyler \& Wakslak, 2004; Jackson et al., 2013; Bradford et al., 2020). Here, this is a concept of legitimacy within law enforcement agencies that is entirely in accordance with that used in the procedural justice literature, where the concern is between those agencies and the people they police (Huq et al., 2017). Willed obedience to an authority arises from a sense that it wields power in a justifiable manner, and a perceived duty to obey that authority both reflects and constitutes its legitimacy (Tyler \& Jackson, 2014; Trinkner, 2019; Pósch et al., 2020). Crucially, the feeling of a "moral duty to obey" the instructions of a legitimate authority comes prior to the particular content of those instructions. Thus, members of organizations where legitimacy is strong will be more likely to accept new ways of working, regardless of what it is they are asked to do.

Perceptions of procedural justice have therefore been strongly linked to employee's sense that the organization is legitimate and to their level of organizational identification and commitment. Identification and legitimacy are two conceptually distinct constructs that we investigate independently here. It is important to note, however, that although identification is typically viewed as an antecedent of legitimacy in the literature (e.g. Bradford et al., 2014b; Bradford et al., 2017), in this study we position them as parallel mediators. We have two reasons for doing so. First, on a practical level the precise nature of the relationship between identification and legitimacy is tangential to our main topic of interest, that is, what procedural constructs might be linked to openness to change in law enforcement organizations. Second, given the nature of those organizations, the relationship between identity and legitimacy may in itself be quite complex. For example, officers may draw from their relationships with colleagues and immediate supervisors to inform their sense of themselves as 'police', but distinguish this from how they feel about the senior managers who ask, or in most cases order, them to engage in programs of change (Hoggett et al. 2019; c.f. Bowling et al. 2019). Again, such questions are not central to our purpose here. We treat identification and legitimacy as parallel mediators because we see that as the most parsimonious approach to take in the face of such potential complexity.

Another issue is whether procedural justice, identification, and legitimacy are more important than instrumental factors in overcoming resistance to change. Rational choice models of human behavior are common approaches to try to motivate compliance (Tyler, 2011). Such instrumental approaches suggest, first, that people respond to the risk of sanction, and comply with new rules and policies when they believe they will be punished in some way if they do not. Second, it assumes that people respond to the promise of reward, and comply when they feel they will gain from doing so. However, there is little evidence to suggest that either punishment or reward promote behavioral change in a consistent, long-lived manner. In this project, we focus on intrinsic motivations linked to institutional identification and commitment, which may be more powerful and long-lasting factors in promoting change.

\section{Change in Law Enforcement Interrogation Practices}

Empirical research on interrogation spans several decades, with early research drawing attention to problematic psychological practices that lead to false confessions and wrongful convictions (Drizin \& Leo, 2004; Leo \& Davis, 2010; Norris et al., 2019). Partly as a reaction to faulty tools promoted in 
interrogation manuals and displayed in practice (Gudjonsson, 2003), researchers have responded by developing evidence-based techniques that yield more reliable, diagnostic information. Such efforts have resulted in a body of research that is now significant in size and scope (Brandon et al., 2018; Bull et al., 2009; Meissner et al., 2017). Many of these evidence-based techniques stand in stark contrast with common practices, at least in the U.S. (Brimbal et al., 2019). Further, these techniques were developed and tested in large part by researchers and not law enforcement practitioners. Often times, academics are providing or assisting with the training in these techniques, thus increasing resistance in an already skeptical population (Bowling et al., 2019).

\section{Current Studies and Their Contribution}

What, then, might enable the acceptance of new practices (such as evidence-based interrogation practices) within police organizations? The current studies were an initial attempt to answer this question by providing evidence of the barriers to change and potential avenues to overcome these barriers. The purpose of the first study was to examine predictors of openness to implementing change in interrogation practice. Prior research in law enforcement contexts points to the importance of culture, procedural justice and organizational identification and commitment as factors shaping legal actors' openness to new practices and policies. Instrumental levers that seek to bribe or force people to change their behavior seem to be less effective in promoting change (Bradford et al., 2013; Tyler \& Blader, 2000). The second study linked these factors to law enforcement's propensity to implement evidencebased interview tactics they were trained in.

In this paper, we drew on two sets of data. The first was based on a large sample of law enforcement officials, all of whom were previously trained in evidence-based practices at the Federal Law Enforcement Training Center (FLETC). A survey asked research participants about the level of procedural justice in their organization, their sense of the rewards and sanctions involved in their dayto-day work, their sense of empowerment within their role, and their willingness to comply with directives and engage in extra-role behavior. We assessed whether procedural justice is more important in explaining variation in empowerment, compliance and extra-role behavior than rewards and sanctions. While others have modelled legitimacy as a potential mediator of the effect of a procedurally just organizational climate on officer outcomes including extra-role behavior (e.g., Trinkner et al., 2016), few studies have considered identification and (internal) legitimacy in the same analysis. Further, they did not investigate compliance, empowerment and extra-role behavior as outcomes indicative openness to change, nor did they assess these constructs within the context of law enforcement investigators. In our second study, we focused on how procedural justice and active/positive behavior within the organization all relate to compliance, empowerment, and extra-role behavior as well as predicted future use of evidence-based interviewing practices after training.

Our goal in these two studies was to establish a baseline level of evidence, for future research to build upon, on the role that procedural justice may play in motivating active and positive behavior within the organization, and compare the role that procedural justice plays compared to the more rational choice aspects of reward and sanction, within law enforcement. We hypothesized that a procedurally fair organizational climate (from management and supervisors) would predict outcomes tied to organizational change (i.e., compliance, extra-role behavior, and empowerment), mediated by organizational identification and perceived legitimacy. Further we predicted that procedural justice factors would be stronger predictors than outcome-oriented factors such as reward and sanctions.

We examined this type of model within a population not previously evaluated: law enforcement officers. We surveyed them about their perceptions of their own organizations and, additionally in Study 2 , their attitudes towards implementing evidence-based interviewing practices.

\section{Participants}

\section{Study 1: Method}

Our sample was large and diverse, both geographically and organizationally. Participants were U.S. Law Enforcement Officers (LEOs; $N=711$ ) from around the country, recruited because they had previously attended criminal investigator or advanced interview training courses at the Federal Law Enforcement Training Center (FLETC) in Glynco, Georgia. Approximately 6,800 emails were sent out to previous trainees asking them to voluntarily complete a survey designed to take 20-30 minutes. Eleven percent of the LEOs contacted responded. Although this response rate might seem low, we 
speculate that it is largely due to the fact that the survey was administered online and we invited a very large number of LEOs to participate with no incentive to respond (Nix et al., 2019). Respondents were aged from 22 to $81(M=36.14, S D=8.51)$, mostly male $(n=494)$, with fewer females $(n=130)$, and some unreported $(n=89)$. The sample was predominantly Caucasian $(n=470)$ followed by non-White Hispanic $(n=53)$, Black/African American $(n=39)$, Asian $(n=26)$, Other/Mixed $(n=16)$, Native American $(n=13)$, and Pacific Islander $(n=4)$. Respondents reported working for a broad number of different government agencies (145 in total) distributed across federal (non-military, $n=391$; military, $n=80)$, state $(n=8)$, and local law enforcement $(n=51)$ agencies. Furthermore, this was a fairly experienced sample reporting lengths of experience from less than a year to 44 years $(M=9.46 ; S D=$ 7.62).

\section{Survey Measure}

We developed a survey to test the model depicted in Figure 1 and our hypotheses. The survey contained 77 items (measuring nine independent constructs, all available in Online Supplement A on the first author's OSF account; osf.io/qczxb) that participants responded to on seven-point Likert-type scales ranging from Strongly disagree (1) to Strongly agree (7), including Disagree (2), Somewhat disagree (3), Neither agree nor disagree (4), Somewhat agree (5), and Agree (6). Items that were phrased negatively were reverse coded. This questionnaire was followed by a short demographic questionnaire.

Predictors. Our four predictors were supervisory procedural justice (e.g., "My supervisor gives me the chance to voice my opinion about decisions that affect me"), management procedural justice (e.g., "Senior managers are open and honest with staff"), appropriateness of sanction (e.g., "I would be held accountable if I under-performed in my role") and reward (e.g., "I think I'm poorly paid for the role I perform in this agency").

Outcome variables. Our three outcome variables were compliance (e.g., "I comply with the agency's policies, even when I think they are wrong"), empowerment (e.g., "I am confident about using my own judgment at work"), and extra-role behavior (e.g., "I' $d$ go the extra mile at work if it helps the agency").

Mediating variables. We also had two mediating variables: organizational identification (e.g., "I feel a sense of loyalty to the organization that I work for") and legitimacy (e.g., "It is important that people ultimately respect their supervisor's decisions").

\section{Procedure}

All procedures for this study were approved by the City University of New York Institutional Review Board. Participants were sent an email containing a link to our survey. The email explained that researchers were collecting data on law enforcement officers' attitudes and beliefs about their agency. We assured recipients that the survey would be anonymous and absolutely no identifiable information would be collected, and that the link would not be affiliated with their email address. They were also asked to complete the survey within two weeks of receiving the email. The survey was administered via Qualtrics. Participant were only allowed to respond to questions after having agreed to our internet based informed consent. Once they had completed the survey, participants were thanked for their participation.

\section{Study 1: Results}

All data used for this study are included on the first author's OSF account (osf.io/qczxb). The first step in the analysis was to assess the measurement properties of the various psychological constructs used to predict compliance, empowerment and extra-role behavior. We confirmed the distinctiveness and assessed the scaling properties of our sets of indicators by using Confirmatory Factor Analysis (CFA) models, estimated using MPlus 7.2. Full information maximum likelihood estimation to account for missing data throughout the dataset. All indicators were set to be categorical given the nature of the scales used. Table 1 presents the fit statistics for seven CFA models. The fit of Models 2, 3, 4, 5, 6 and 7 was poor according to the approximate fit statistics, with the CFI and TLI fit indices all below the standard cut-off point of 0.95 (Hu \& Bentler, 1999) and the Root Mean Square Error of Approximation (RMSEA) fit indices all above .08. Model 1, comprised of our six empirically distinct psychological constructs (i.e., supervisory procedural justice, management procedural justice, sanction, reward, organizational identification, and legitimacy) showed the best fit, $\chi^{2}(260)=1453, p<.001$. Indeed, CFI (.96) and TLI (.96) were both greater than .95 and RMSEA (.08) was at the high end of the fit index, all 
three of these indicating good fit (Hu \& Bentler, 1999). The measurement properties for each of the six constructs from this model were also good (i.e., factor loadings $>.59$, see Comrey \& Lee, 1992). For bivariate correlations between the six latent variables, see Table 2; for a more specific breakdown of $R^{2}$ values and factor loadings, see Table 3 ).

The final stage of analysis used Structural Equation Modelling (SEM) to examine the various theoretical propositions driving the current study. The goal was to examine the extent to which normative factors (procedural justice, organizational identification and legitimacy) explained variation in the three key potential outcomes, compared to instrumental factors (sanctions and rewards). We fit three separate SEMs - the first for compliance, the second for empowerment, and the third for extrarole behavior. As described earlier in the paper, these constructs represent key underlying factors that drive openness to change and willingness to comply with directives from superiors regarding potential change in practice.

\section{Compliance}

For compliance (see Figure 2 and Table 4), the fit of the model was acceptable according to the approximate fit indices (CFI and TLI close to 0.95 and RMSEA less than 0.08). Moving from left to right, we see that a relatively large amount of variation in organizational identification was explained $\left(R^{2}=.68\right)$ by an additive linear combination of supervisor procedural justice, management procedural justice, sanctions and rewards. The factor that was the strongest predictor of organization identification was management procedural justice $(B=.39, p<.001)$. The more people believed that senior managers in their organization were fair, open and honest, the more likely they were to identify with the organization and feel respected. There was a similarly positive association between supervisory procedural justice and organization identification (albeit with a smaller standardized regression coefficient, $B=.22, p<.001)$. Feeling rewarded by the institution was also associated with stronger identification $(B=.31, p<.001)$. Compared to organizational identification, less of the variance of legitimacy was explained by the model $\left(R^{2}=.35\right)$. The strongest predictor was again management procedural justice $(B=.41, p<.001)$, followed by supervisor procedural justice $(B=.17, p=.001)$ and sanctions $(B=.16, p<.001)$, while rewards was not predictive $(B=.00 p=.98)$.

Overall, procedural justice seemed to be central to identification and legitimacy, with rewards as a predictor of identification $(B=.31, p<.001)$ and sanctions a predictor of legitimacy $(B=.16, p<$ $.001)$. Turning to the predictors of compliance, we found that $43 \%$ of the variance could be explained by the four predictors. Legitimacy had the strongest statistical effect $(B=.51, p<.001)$ : the more people felt a duty to respect and back the decisions of their supervisor and senior managers, the more likely they were to follow the rules and correct procedures, even if they disagreed with the content. Organizational identification more weakly predicted compliance, and negatively $(B=-.15, p=.03)$. The other two statistically significant predictors were rewards and sanctions: the more people felt rewarded by the institution, the more likely they were to say they would comply $(B=.24, p<.001)$, and the more people felt they would be held to account for poor performance, the more likely they were to comply $(B=.21, p<.001)$. We thus found support for both a normative account of compliance (because management procedural justice indirectly predicted compliance and legitimacy directly predicted it) and an instrumental account of compliance (because rewards and sanctions also explained some of the variance). Yet, as with previous research, instrumental factors were not the strongest predictors of compliance.

\section{Empowerment}

Figure 3 and Table 5 summarize the same fitted model as with compliance, replacing it with empowerment (i.e., the feeling of being trusted to make important work decisions, of confidence in their own judgements, feeling comfortable with a new set of guidelines to follow, and so forth). As with compliance, a fair amount of variation was explained $\left(R^{2}=.55\right)$ but unlike compliance, the key factor was organizational identification $(B=.56, p<.001)$ not legitimacy $(B=.05, p=.25)$. Indeed, both supervisory $(B=.14, p<.001)$ and management $(B=.22, p<.001)$ procedural justice had significant indirect effects on empowerment through organizational identification. Sanctions were a significant negative predictor, although weak $(B=-.08, p=.04)$, while rewards were a significant positive predictor $(B=.21, p<.001)$, again as previously, instrumental predictors were not as strong of a predictor as the normative predictors of empowerment. 


\section{Extra-Role Behavior}

Finally, Figure 4 and Table 6 turns to extra-role behavior (the willingness to take on extra work to help colleagues and the institution). The findings were similar to empowerment, albeit with less of the variance explained $\left(R^{2}=.39\right)$. The key factor was organizational identification $(B=.60, p<.001)$, given that legitimacy had a weaker statistical effect $(B=.17, p<.001)$ in this model. Both supervisor $(B=$ $.16, p<.001)$ and management $(B=.26, p<.001)$ procedural justice had significant indirect effects on extra-role behavior via both identification and legitimacy. Neither sanctions $(B=-.02, p=.54)$ nor rewards $(B=-.11, p=.12)$ were significant predictors of extra-role behavior.

\section{Study 1: Discussion}

Results showed overall support for our model. Law enforcement investigators who felt like their supervisors and management team behaved in a procedurally fair and just way identified with their organization to a higher extent and perceived their organization as more legitimate. These factors in turn positively predicted compliance, empowerment, and extra-role behavior, with organizational identification and legitimacy as mediating variables. Finally, normative accounts of compliance, empowerment, and extra-role behavior were stronger than instrumental predictors. In fact, of the three outcomes, sanctions only significantly predicted compliance. These results are encouraging in that, in line with other recent contributions (e.g. Bradford et al. 2013; Trinkner et al. 2016), they support that the broader procedural justice literature can be applied to a law enforcement sample, despite this population's (in)famous penchant for skepticism and hesitancy towards change (e.g., Skogan, 2008; Bowling et al., 2019).

\section{Study 2: Method}

Given the encouraging results from these survey data, we sought to replicate and extend this model in a more specific, operational, context. We asked: Does this model predict openness as it is manifested by interviewers' reactions to training that may be novel to many of those interviewers? Indeed, most law enforcement interview trainings are based on anecdotal practitioner experience, presented by their peers and not evidence-based practices, presented by researchers (Gudjonsson, 2003). To test this, we included questions from Study 1 in a questionnaire that law enforcement interviewers completed at the end of evidence-based training on rapport and trust building techniques. Although a rapport-based approach to interviewing is highly encouraged by researchers (Meissner et al., 2017), practitioners have predominantly been trained in coercive techniques that are completely divergent in terms of ethos and tactical approach. Thus, we tested our model within the context of this novel interview training.

\section{Participants}

A convenience sample was recruited, composed of LEOs from several local and federal agencies from across the United States. Participants were mostly Male (74.6\%) and White $(80.30 \%)$ with some Black or African American (8.5\%) and Hispanic (5.6\%) officers. Their age ranged from 26 to 58 in age $(M=$ $39.96, S D=7.28)$ and were fairly experienced $(M=13.60$ years, $S D=7.07$ years). We recruited LEOs to participate in a two-day training on evidence-based interviewing techniques. LEOs participated in this training as part of a validation study of the techniques they were being trained in (Brimbal et al., 2020). The main purpose of the study was to evaluate trainability and effectiveness of these techniques on semi-cooperative sources, however, because the training was based in science, LEOs were also asked to respond to items from Study 1 to evaluate the link between trainees' attitudes and their likelihood to implement the techniques in the field. Seventy-eight LEOs participated in at least one day of the training but due to attrition related to time sensitive job duties, only 71 LEOs were present at the end of the training and thus were able to respond to our survey. This number of participants is not commonly acceptable to test a model of the level of complexity as our Study 1 model. However, administering what might be considered sensitive questions about LEO's organization at their workplace with supervisors present, in the context of evidence-based training is a delicate task not easily achieved.

\section{Materials}

Given time constraints of the training we were only able to provide officers with one or two items for each construct included in the model presented in Study 1, chosen given their good fit within the construct they represented. The subset of items included in our analyses is indicated on the first author's 
OSF account (osf.io/qczxb). Because recruitment for this training was not uniform (certain officers were mandated to attend the training, others volunteered), we thought that individual motivation to attend the training was both relevant and independent from and not necessarily predicted by a procedurally fair organizational climate. Thus, we also measured participants' intrinsic motivation to attend this particular training. Finally, we asked them how familiar they were with each component of the training (detailed below) and how likely they were to use each component in the field on 7-point Likert scales. Although each of the components of the training was different and interviewers might be more or less likely to use each one in the field, we were interested in likelihood of future use of the entire evidence-based training. Furthermore, participants responses for each component were fairly well correlated $(.38<r s$ $<.85, p s<.001$ ) and fit together reliably (familiarity ratings: $\alpha=.87$ and likelihood of future use ratings: $\alpha=.85$ ) and thus we averaged ratings of all five components for both familiarity from 1 (completely unfamiliar) to 7 (completely familiar) and likelihood of future use from 1 (completely unlikely) to 7 (completely likely).

\section{Procedure}

All procedures for this study were approved by the Iowa State University Institutional Review Board. Participants took part in a two-day course on evidence-based interview techniques training them to build rapport and trust with interviewees. The training consisted of five sections, each of which were accompanied by practical exercises. The topics covered were (a) good questioning practices (e.g., Griffiths \& Milne, 2006), (b) principles of motivational interviewing adapted to investigative interviewing (Alison et al., 2014), (c) tactics to recognize and manage resistance (e.g., Kelly et al., 2016), (d) trust building tactics (Oleszkiewicz et al., 2020), and (e) rapport building tactics (for review, see Brimbal et al., 2019). The training team was composed of two practitioners with intelligence gathering backgrounds and one researcher. Once they had completed the training, LEOs were provided with questions about the training including questions about procedural justice within their respective agency, administered in person.

\section{Study 2: Results}

All data used for this study are included on the first author's OSF account (osf.io/qczxb). Participants were overall only moderately familiar with the components of the training $(M=4.31$, $S D=1.47$ ), supporting the idea that this was a novel approach to interviewing. Despite concerns over statistical power, we ran several path analyses in an attempt to replicate and build on our findings for Study 1. Full information maximum likelihood estimation to account for missing data throughout the dataset. Because neither sanction nor reward were significant predictors in any of our models and of less interest to this research, we removed them from the models for the sake of statistical power. We also collapsed management and supervisor procedural justice into one factor, given the relative strength of the correlation between them $(r=.44, p<.001)$ and, again, to maximize statistical power. Finally, we included motivation to attend the training as a predictor for likelihood of future use (only) to address interest and intrinsic motivation in the particular training participants took part in, independent of their perceptions of their organization.

\section{Likelihood of Future Use}

For the model predicting likelihood of future use, we added motivation to attend the training to the model tested in Study 1 (see Figure 5 for the fitted model and Table 7). The fit of the model was acceptable according to the approximate fit indices (CFI close to 0.95 and RMSEA less than 0.08 ). The model accounted for $24 \%$ of the variance, however it only partially replicated our Study 1 findings, with only procedural justice predicting legitimacy $(B=.38, p=.005)$ and organizational identification $(B=.31, p=.01)$, while the key factor predicting likelihood of future use in this model was motivation to attend training $(B=.46, p<.001)$. Organizational identification also played a role, marginally predicting likelihood of future use $(B=.14, p=.10)$.

\section{Compliance}

For compliance, the model fit was also adequate (CFI and TLI close to 0.95 and RMSEA less than 0.08 ) and the model accounted for $29 \%$ of the variance (see Figure 6 and Table 8). In this model, the indirect effect between procedural justice and compliance was significant $(B=.20, p$ 
$=.01)$ with procedural justice predicting legitimacy $(B=.36, p=.006)$, in turn predicting compliance $(B=.55, p<.001)$. Thus, as in Study 1 , the key mediator for compliance was legitimacy. Furthermore, procedural justice also predicted organizational identification $(B=.30$, $p=.01)$, however organizational identification did not significantly predict an increase in compliance, again as in Study 1.

\section{Empowerment}

The model fit for empowerment was moderate (CFI close to 0.95; see Figure 7 and Table 9). However, while procedural justice again predicted organizational identification $(B=.30, p=.01)$ and legitimacy $(B=.36, p=.006)$, neither of these predicted empowerment and no other paths were significant, unlike in Study 1.

\section{Extra-Role Behavior}

Similarly, as for compliance, model fit was good (CFI close to 0.95 and RMSEA less than 0.08) and as for both compliance and empowerment, procedural justice predicted organizational identification $(B=.30, p=.01)$ and legitimacy $(B=.36, p=.006)$. On the other hand, only identification marginally predicted extra-role behavior $(B=.25, p=.09)$ and the indirect effect was not significant $(B=.07, p=.19)$, tentatively suggesting that identification was more important than legitimacy in this model, as it was in Study 1 when predicting extra-role behavior. See Figure 8 and Table 10 for full statistics.

\section{Between Study Comparisons}

One reason our results might be different is that our two samples were collected in two different environments. In Study 1, participants were recruited online and responded to the survey voluntarily, at their own convenience, in an environment that was comfortable for them. In Study 2 , participants were part of a training study that they might not have participated in voluntarily. Further, they responded to the survey in a room with other investigators - they used the device of their choice (their own or one provided by the research team), but were in close proximity with other investigators. Thus, it was possible that this might account for differences between samples. We compared participants' responses with a MANOVA to assess for these potential differences (see Table 11 for full results). Box's M was significant $(p<.001)$ most likely due to our unequal cell size, thus we used Pillai's Trace to interpret our results finding that the MANOVA was indeed significant, Pillai's Trace $=.07, F(9,684)=5.90, p<.001$. When comparing marginal means from significant univariate follow-up ANOVAs between responses from Study 1 to Study 2, we indeed found that participants from Study 2 reported higher ratings of procedural justice both supervisory $(d=0.30,95 \% \mathrm{CI}[0.07,0.54])$ and management $(d=0.53,95 \% \mathrm{CI}[0.28,0.78])$, and higher ratings of rewards $(d=0.68,95 \%$ CI $[0.41,0.95])$ but not sanctions $(d=0.24,95 \%$ CI [$0.03,0.50])$. Participants also responded higher in Study 2 than in Study 1 to questions about organizational identification $(d=0.66,95 \%$ CI $[0.42,0.91])$ but not legitimacy $(d=-0.18,95 \%$ CI [-0.44, 0.09]). In terms of the outcomes in our model, empowerment ( $d=0.54,95 \%$ CI [0.27, $0.81])$, and extra-role behavior $(d=0.37,95 \%$ CI $[0.11,0.64])$ were reported as significantly higher for Study 2 compared to Study 1, but not compliance $d=-0.17,95 \%$ CI [-0.44, 0.09]).

\section{Study 2: Discussion}

Results of this second study were not as conclusive as those of Study 1. We found that motivation to attend the training was, rather unsurprisingly, the most important factor predicting likelihood of future use of the evidence-based tactics interviewers were trained in. We also partially replicated the findings of Study 2 with models predicting compliance and extra-role behavior, indicating that even in an underpowered sample, procedural justice factors were related to these openness to change outcomes. Given our small sample and the inability to include the complete set of questions utilized in Study 1, some results are still notable. In all of our models, procedural justice of both supervisors and managers predicted both identification and legitimacy, mirroring the strong effects found in Study 1. Motivation to attend the training positively predicted likelihood of future use, which means that beyond LEOs' perceptions of their organizations, their individual interest and willingness to take part in a specific training (and be receptive to research- 
based interviewing) would be the best predictor of them implementing a novel, rapport-based interviewing approach in the field. However, individual level of motivation as a predictor of willingness to entertain new ideas is not necessarily helpful in implementing change programs in otherwise unwilling populations. On a positive note, procedural justice principles appeared to play a role in LEOs' reported likelihood of future use and the same outcomes as in Study 1, although not in as straightforward a manner as Study 1. Most notably, procedural justice predicted legitimacy which in turn predicted compliance. There was no such effect through organizational identification, thus in a similar manner as in Study 1, legitimacy was a key mediator in predicting compliance. Further, the marginal effect of identification on extra-role behavior supports the relative importance of this construct in comparison to legitimacy when predicting extra-role behavior. Given our substantial lack of statistical power in this study, our marginal effects of organizational identification on likelihood of future use and extra-role behavior are encouraging, although they should be taken with a grain of salt. On the other hand, the fact that Study 2 outcome-oriented factors (i.e., fairness of sanctions and rewards) were not predictive of likelihood of future use, compliance, empowerment, and extra-role behavior supports the idea that these are not as effective at producing change oriented outcomes.

Interestingly, participants responses in Study 2 were significantly higher on most items questioned about than in Study 1. This shows that even when provided with some privacy, Study 2 participants still rated their attitudes and behaviors significantly more positively than law enforcement officials provided with more anonymity online. These differences suggest that we may not have captured the full range of their attitudes and behaviors towards their organizations and superiors: Our Study 2 participants may not have felt comfortable to provide their true opinions - especially negative ones - and might have rated their supervisors more positively than they truly saw them or their workplace as fairer than they actually believed it to be.

\section{General Discussion}

These two studies provide some support for the importance of a procedural justice within law enforcement organizations. Study 1 replicated a model of procedurally just organizational climate (cf. Trinkner et al., 2016) with a broad law enforcement sample, including investigators and interviewers coming from a wide range of organizations, illustrating its generalizability and utility in the field. Findings in Study 2 were less straightforward, as the fitted models were not as clearly supportive of our hypotheses. However, the findings did suggest the importance of procedural justice concerns (especially in comparison to instrumental factors such as sanctions and rewards) when considering interviewers' likelihood to use a new, evidence-based interviewing approach in the future, their likelihood to comply, feelings of empowerment, and extra-role behavior. Although Study 2 showed mean differences in responses compared to Study 1 , suggesting that officers might not be disclosing their true attitudes and behaviors to the same extent as they did in Study 1, this study still provided us with the opportunity to test our model within a more tangible setting.

Generally, our findings suggest that officers who perceive their organizations as functioning in a procedurally just manner, and see both upper management and their direct supervisors as fair, transparent, and trustworthy, also tend to view themselves as an important part of their organization and think that its policies are in line with their own values. Those officers are in turn more likely to go above and beyond their job duties, feel entrusted to make decisions in the field, and comply with requests from superiors - even when disagreeing with them or failing to understand them. These officers will be most open to implementing change programs and most adaptable and open to employing evidence-based interview techniques (e.g., a rapport-based approach to interviewing). Furthermore, although no causal link can be established due to the observational nature of our data, it is plausible to suggest that organizations displaying the characteristics described earlier are most likely to be successful in their implementation of evidence-based interview techniques. Thus, the climate of a particular law enforcement organization might be a good indicator as to whether implementing programs of change will be successful or not. Furthermore, organizations with a particularly procedurally fair climate could be identified and targeted for the piloting of programs of change. 
Much research involving procedural justice in law enforcement focuses on how frontline officers' exercise of procedural justice principles might improve police and private citizen interactions. We find here that these same principles of procedural justice, when employed within a police organization might improve frontline officers' experience of their work environment making them more likely to comply with changes in practices, such as using evidence-based interviewing strategies. This is especially important because using evidence-based interviewing such as a rapport-based approach that involves empathy, respect, and understanding can improve interactions within an interview room and beyond. Principles of procedural justice should then not only be employed by law enforcement but within law enforcement agencies so as to stimulate change within practices.

With these studies, we aimed to evaluate concepts of procedural justice within a law enforcement context. Both samples in our studies were novel and unique for their generalizability. Our first represented a broad range of U.S. law enforcement agencies and organizations and our second was composed of law enforcement officers who were, for the most part, experienced interviewers and routinely conducted interrogations also from a broad range of both federal and local law enforcement. Replicating the model is encouraging as it implies the generalizability of past procedural justice research to this population. Thus, our research is an important addition to the literature as we applied procedural justice theory to a context where it would be highly useful, given previous failures in programs of change (e.g., Skogan, 2008). These results also broaden the scope of the procedural justice literature and are a first step in identifying potential factors that might influence law enforcement towards the successful adoption of evidence-based practices.

\section{Limitations and Future Directions}

First, we are limited in that it is possible that participants' impressions of their organizations (i.e., management, supervisors, sanctions and rewards) are not accurate and that reported likelihood of future use (Study 2) will not be reflected in actual future use. Second, our data were observational in nature. We did not control nor manipulate variables in our studies and thus we cannot make any claim to causation. Further, despite our efforts to model mediations, our items were presented in an order that does not mirror our model (outcomes, then mediators, then predictors) and not randomized given an initial attempt to distribute the survey in-person as well as online. In experimental work, it is important to measure the mediator before the dependent variable (because the design permits causal claims), but in cross-sectional survey work when no such causal claims are made, it is only important if one thinks there are question order effects. Future research should replicate our findings using experimental design and causal mediation analysis methods that are beyond the scope of this paper (e.g., Pósch et al., 2020) and build on our findings by manipulating similar predictor variables to measure their effect on similar mediators and outcomes.

Although in Study 1 we were able to gather an impressively large and representative sample of law enforcement officers, our response rate was fairly low, which although not unexpected given the number of recruitment emails sent out and the fact that it was administered online (Nix et al., 2016), still limits the generalizations we might make from this sample. Our survey was quite lengthy and the topic might have been considered sensitive to certain officers, especially those who might not have a positive view of their organization. Thus, it is possible that our sample gathered LEOs who were both particularly assiduous and satisfied in their work place. Future research should be sure to test this model with officers who might be more discontent with their organization.

The large sample size was a strength for Study 1, however, unfortunately this was not the case for Study 2. Given our convenience sample and the difficulty to recruit LEO samples to a training delivered over several days, our path analyses are severely underpowered in Study 2. Indeed for path analysis the recommendation is to have a sample of at least 100 to 150 participants, especially given the complexity of our model (Tabachnick \& Fidell, 2019). Further, our replication of the Study 1 model in Study 2 was limited because we were only able to ask our sample one or two questions for each construct in the model, and the necessity to simplify our model to accommodate our small sample size. However, given the rarity of such training studies, 
these results are nonetheless important as they still suggest the importance of our procedural justice factors over outcome factors. Future research should attempt to better test the model in a more generalizable setting with a larger sample and with behavioral measures instead of observational ones. Future research should also attempt to assess the extent to which it is possible to move beyond the correlational nature of the relationships in our studies and use our predictive model to implement change within an organization.

\section{Conclusion}

In conclusion, we were able to find support for our model predicting factors hindering and promoting openness to change, supporting the importance of procedural justice factors when compared to outcome-oriented factors such as reward and sanctions. These studies add to the literature by applying a procedural justice framework to predict openness to change and likelihood of future use of evidence-based interview techniques. While among LEOs individual openness to change may be the most important factor predicting willingness to, here, attend a training course on evidence-based interrogation techniques and take up the methods the course suggested, procedural justice within organizations was also important. If we took two individuals from Study 2 with the same motivation to attend the course, the person who found their supervisors and senior managers to be fairer was more likely to say they would act on the course contents. This suggests that procedural justice concerns may work alongside or in tandem with the individual propensities of LEOs to engage with evidence-based practice. At the margins, reconfiguring law enforcement agency's structures and processes in ways aligned with the concept of procedural justice could enhance employee 'buy-in' to programs of change. 


\section{References}

Alison, L., Alison, E., Noone, G., Elntib, S., Waring, S., \& Christiansen, P. (2014). The efficacy of rapport-based techniques for minimizing counter-interrogation tactics amongst a field sample of terrorists. Psychology, Public Policy, and Law, 20, 421-430. doi: 10.1037/law0000021

Ashworth, B. E., \& Mael, F. (1989). Social identity theory and the organization. The Academy of Management Review, 14, 20-39.

Bayley, D. H. (2008). Police reform: Who done it? Policing and Society, 18, 7-17.

Blader, S., \& Tyler, T. R. (2009). Testing and extending the group engagement model: Linkages between social identity, procedural justice, economic outcomes, and extrarole behavior. Journal of Applied Psychology, 94, 445-464.

Boba, R., \& Crank, J. P. (2008). Institutionalizing problem-oriented policing: Rethinking problem solving, analysis, and accountability. Police Practice and Research, 9, 379-393.

Bowling, B., Reiner, R. and Sheptyki, J. (2010). The Politics of the Police (5th ed.). Oxford, UK: Oxford University Press.

Bradford, B., \& Quinton, P. (2014). Self-legitimacy, Police Culture and Support for Democratic Policing in an English Constabulary. British Journal of Criminology, 54, 1023-1046. doi: $10.1093 / \mathrm{bjc} / \mathrm{azu} 053$

Bradford, B., Quinton, P., Myhill, A., \& Porter, G. (2014a). Why do "the law" comply? Procedural justice, group identification and officer motivation in police organizations. European Journal of Criminology, 11, 110-131.

Bradford, B., Murphy, K., \& Jackson, J. (2014b). Officers as mirrors: Policing, procedural justice and the (re)production of social identity. British Journal of Criminology, 54, 527-500.

Bradford, B., Milani, J., \& Jackson, J. (2017). Identity, legitimacy and "making sense" of police use of force. Policing: An International Journal of Police Strategies and Management, 40, 614-627.

Bradford, B., Yesberg, J., Jackson, J., \& Dawson, P. (2020). Live facial recognition: Trust and legitimacy as predictors of public support for police use of new technology. British Journal of Criminology. https://doi.org/10.1093/bjc/azaa032

Brandon, S. E., Wells, S., \& Seale, C. (2018). Science-based interviewing: Information elicitation. Journal of Investigative Psychology \& Offender Profiling, 15, 133-148. https://doi.org/10.1002/jip.1496

Brimbal, L., Kleinman, S. M., Oleszkiewicz, S. \& Meissner, C. A. (2019). Developing rapport and trust in the interrogative context: An empirically-supported and ethical alternative to customary interrogation practices. In S. J. Barela, M. J. Fallon, G. Gaggioli, \& J. D. Ohlin (Eds.), Interrogation and Torture: Integrating Efficacy with Law and Morality. Oxford University Press.

Brimbal, L., Meissner, C. A., Kleinman, S. M., Phillips, E. L., Atkinson, D. J., Dianiska, R. E., Rothweiler, J., Oleszkiewicz, S., \& Jones, M. S. (2020). Evaluating the benefits of an evidencebased approach to investigative interviewing: A training study with law enforcement investigators. Manuscript submitted for publication.

Bull, R., Valentine, T., \& Williamson, T. (2009). Handbook of psychology of investigative interviewing: Current developments and future directions. John Wiley \& Sons.

Colquitt, J. (2008). Two decades of organizational justice: Findings, controversies, and future directions. In C. Cooper \& J. Barling (Eds.), The Sage Handbook of Organizational Behavior (pp. 73-88). Sage.

Colquitt, J., Conlon, D., Wesson, M., Porter, C., \& Ng, K. (2001). Justice at the millennium: A metaanalytic review of 25 years of organizational justice research. Journal of Applied Psychology, 86, 425-445.

Comrey, A. L., \& Lee, H. B. (1992). A first course in factor analysis ( $2^{\text {nd }}$ ed.). Erlbaum.

Cordner, G. (2000). 'Community policing: elements and effects'. In G. Alpert \& A. Piquero (Eds.), Community Policing: Contemporary Readings (pp. 45-62). Waveland Press.

De Cremer, D., \& Tyler, T. R. (2005). Managing group behavior: The interplay between procedural justice, sense of self, and cooperation. Advances in Experimental Social Psychology, 37, 151-218.

Drizin, S. A., \& Leo, R. A. (2004). The problem of false confessions in the post-DNA world. North Carolina Law Review, 82, 891-1007.

Foster, J. (2003). Cop cultures. In T. Newburn (Ed.) The Handbook of Policing (pp. 196-227). Willan. 
Gau, J., \& Gaines, D. (2012). Top-down management and patrol officers' attitudes about the importance of public order maintenance: A research note. Police Quarterly, 15, 45-61.

Griffiths, A., \& Milne, R. (2006). Will it all end in tiers? Police interviews with suspects in Britain. In T. A. Williamson (ed.) Investigative Interviewing: Rights, Research, Regulation (pp. 167-189). Willan.

Gudjonsson, G. H. (2003). The psychology of interrogations and confessions: A handbook. John Wiley \& Sons.

Haas, N. E., Van Craen, M., Skogan, W. G., \& Fleitas, D. M. (2015). Explaining officer compliance: The importance of procedural justice and trust inside a police organization. Criminology and Criminal Justice Advance Access, 15, 442-463.

Hartwig, M., Meissner, C. A., \& Semel, M. D. (2014). Human intelligence interviewing and interrogation: Assessing the challenges of developing an ethical, evidence-based approach. In R. Bull (Ed.), Investigative interviewing (pp. 209-228). New York, NY: Springer Science + Business Media.

Hayes, A. F. (2013). Introduction to mediation, moderation, and conditional process analysis: A regression-based approach. New York, NY: Guilford Press.

Hoggett, J., Redford, P., Toher, D. et al. Challenges for Police Leadership: Identity, Experience, Legitimacy and Direct Entry. J Police Crim Psych 34, 145-155 (2019)

Huq, A., Jackson, J. \& Trinkner, R. (2017). Legitimating practices: Revisiting the predicates of police legitimacy. British Journal of Criminology, 57, 5, 1101-1122.

Inbau, F. E., Reid, J. E., Buckley, J. P., \& Jayne, B. C. (2013). Criminal interrogation and confessions (5th ed.). Jones \& Bartlett Learning.

Jackson, J. \& Bradford, B. (2019). Blurring the distinction between empirical and normative legitimacy? A methodological commentary on "Police Legitimacy and Citizen Cooperation in China". Asian Journal of Criminology, 14, 4, 265-289.

Jackson, J., Bradford, B., Hough, M., Myhill, A., Quinton, P., \& Tyler, T. R. (2012). Why do people comply with the law? Legitimacy and the influence of legal institutions. British Journal of Criminology, 52, 1051-1071.

Jackson, J., Huq, A., Bradford, B., \& Tyler, T. R. (2013). Monopolizing force? Police legitimacy and public attitudes towards the acceptability of violence. Psychology, Public Policy and Law, 19, 4, 479-497, doi: 10.1037/a0033852.

Kassin, S. M., Drizin, S. A., Grisso, T., Gudjonsson, G. H., Leo, R. A., \& Redlich, A. D. (2010). Policeinduced confessions: Risk factors and recommendations. Law and Human Behavior, 34, 3-38.

Kelly, C. E., Miller, J. C., \& Redlich, A. D. (2016). The dynamic nature of interrogation. Law and Human Behavior, 40, 295-309. doi: 10.1037/lhb0000172

Leo, R. A., \& Davis, D. (2010). From false confession to wrongful conviction: Seven psychological processes. The Journal of Psychiatry \& Law, 38, 9-56.

Loftus, B. (2010). Police occupational culture: Classic themes, altered times. Policing and Society, 20, $1-20$.

Lum, C. (2009). Translating police research into practice. Washington, DC: Police Foundation (Ideas in American Policing, Series No. 11).

Lum, C., Telep, C. W., Koper, C., \& Grieco, J. (2012). Receptivity to research in policing. Justice Research and Policy, 14, 61-95.

MacQueen, S., \& Bradford, B. (2017). Where did it all go wrong? Implementation failure - and morein a field experiment of procedural justice policing. Journal of Experimental Criminology, 13, 321345.

Meissner, C. A., Redlich, A. D., Michael, S. W., Evans, J. R., Camilletti, C. R., Bhatt, S., \& Brandon, S. (2014). Accusatorial and information-gathering interrogation methods and their effects on true and false confessions: A meta-analytic review. Journal of Experimental Criminology, 10, 459-486.

Meissner, C. A., Surmon-Böhr, F., Oleszkiewicz, S., \& Alison, L. J. (2017). Developing an evidencebased perspective on interrogation: A review of the US government's high-value detainee interrogation group research program. Psychology, Public Policy, and Law, 23, 438-457. doi: 10.1037/law0000136

Murphy, T., Bradford, B. \& Jackson, J. (2016). Motivating compliance behavior among offenders: Procedural justice or deterrence? Criminal Justice \& Behavior, 43, 102-118. 
Münsterberg, H. (1908). On the witness stand: Essays on psychology and crime. The McClure company. Myhill, A., \& Bradford, B. (2013). Overcoming cop culture? Organizational justice and police officers' attitudes toward the public. Policing: An International Journal of Police Strategies and Management, 36, 338-356.

Nix, J., Pickett, J. T., Baek, H., \& Alpert, G. P. (2019). Police research, officer surveys, and response rates. Policing and Society, 29, 530-550.

Norris, R. J., Bonventre, C. L., Redlich, A. D., Acker, J. R., \& Lowe, C. (2019). Preventing wrongful convictions: An analysis of state investigation reforms. Criminal Justice Policy Review, 3, 597626. https://doi.org/10.1177/0887403416687359

Oleszkiewicz, S. Atkinson, D. J., Kleinman, S. M., \& Meissner, C. A. (2020). Trust-building strategies: Facilitating cooperation in an interrogative context. Paper submitted for publication.

Pósch, K., Jackson, J., Bradford, B., \& MacQueen, S. (2020). "Truly free consent"? Clarifying the nature of police legitimacy using causal mediation analysis. Journal of Experimental Criminology. https://doi.org/10.1007/s11292-020-09426-x

Qureshi, H., Frank, J., Lambert, E. G., Klahm, C., \& Smith, B. (2017). Organisational justice's relationship with job satisfaction and organisational commitment among Indian police. The Police Journal, 90, 3-23. doi: 10.1177/0032258X16662684

Reiner, R. (2010). The politics of the police. Oxford University Press.

Riketta, M. (2005). Organizational identification: A meta-analysis. Journal of Vocational Behavior, 66, 358-384. doi: 10.1016/j.jvb.2004.05.005

Skogan, W. (2008). Why reforms fail. Policing and Society, 18, 23-34.

Skogan, W., \& Frydl, K. (Eds.). (2004). Fairness and effectiveness in policing: The evidence. Washington, DC: National Academies Press.

Suchman, M. (1995). Managing legitimacy. Academy of Management Review, 20, 571-610.

Tabachnick, B. G., \& Fidell, L. S. (2019). Using Multivariate Statistics, $7^{\text {th }}$ Edition. Pearson.

Telep, C. W., \& Lum, C. (2014, February). The impact of departmental and officer characteristics on receptivity to research and evidence-based policing. Philadelphia, PA February, Paper presented at the Academy of Criminal Justice Sciences Meeting.

Treviño, L. K., den Nieuwenboer, N. A., Kreiner, G. E., \& Bishop, D. G. (2014). Legitimating the legitimate: A grounded theory study of legitimacy work among Ethics and Compliance Officers. Organizational Behavior and Human Decision Processes, 123, 186-205.

Trinkner, R. (2019). Clarifying the contours of the police legitimacy measurement debate: A response to Cao and Graham. Asian Journal of Criminology, 14, 4, 309-335.

Trinkner, R., Jackson, J. \& Tyler, T. R. (2018). Bounded authority: Expanding “appropriate" police behavior beyond procedural Justice. Law \& Human Behavior, 42, 280-293.

Trinkner, R., Tyler, T. R., \& Goff, P. A. (2016). Justice from within: The relations between a procedurally just organizational climate and police organizational efficiency, endorsement of democratic policing, and officer well-being. Psychology, Public Policy and Law, 22, 158-172.

Tyler, T. R. \& Jackson, J. (2013). Future challenges in the study of legitimacy and criminal justice. In Tankebe, J. and Liebling, A. (eds.) Legitimacy and Criminal Justice: An International Exploration. Oxford: Oxford University Press, pp. 83-104.

Tyler, T. R. \& Jackson, J. (2014). Popular legitimacy and the exercise of legal authority: Motivating compliance, cooperation and engagement. Psychology, Public Policy and Law, 20, 1, 78-95.

Tyler, T. R., \& Blader, S. L. (2000). Cooperation in groups: Procedural justice, social identity, and behavioral engagement. Psychology Press.

Tyler, T. R., Callahan, P., \& Frost, J. (2007). Armed, and dangerous (?): Can self-regulatory approaches shape rule adherence among agents of social control. Law and Society Review, 41, 457-492.

Tyler, T. R., \& Wakslak, C. J. (2004). Profiling and police legitimacy: Procedural justice, attributions of motive, and acceptance of police authority. Criminology, 42, 2, 253-282.

Willis, J. J., \& Mastrofski, S. D. (2014). Pulling together: integrating craft and science. Policing: $A$ Journal of Policy and Practice, 8, 321-329. 


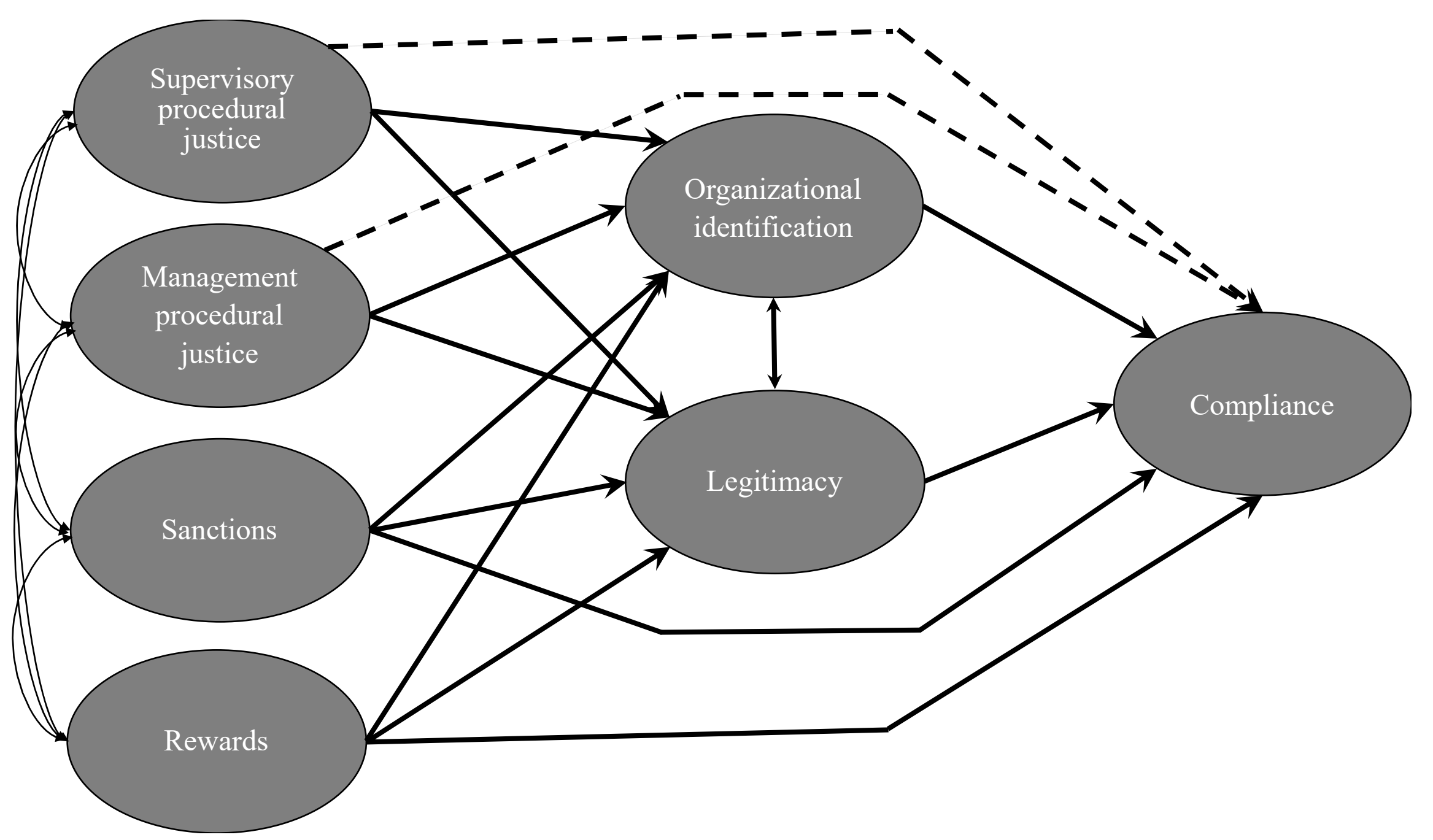

Figure 1. Model tested in Study 1. Dashed line indicate indirect effects, double sided arrows indicate correlations. The paths from sanctions and rewards to organizational identification and legitimacy were included to control for correlation between levels of our model, not because we predicted mediation. 


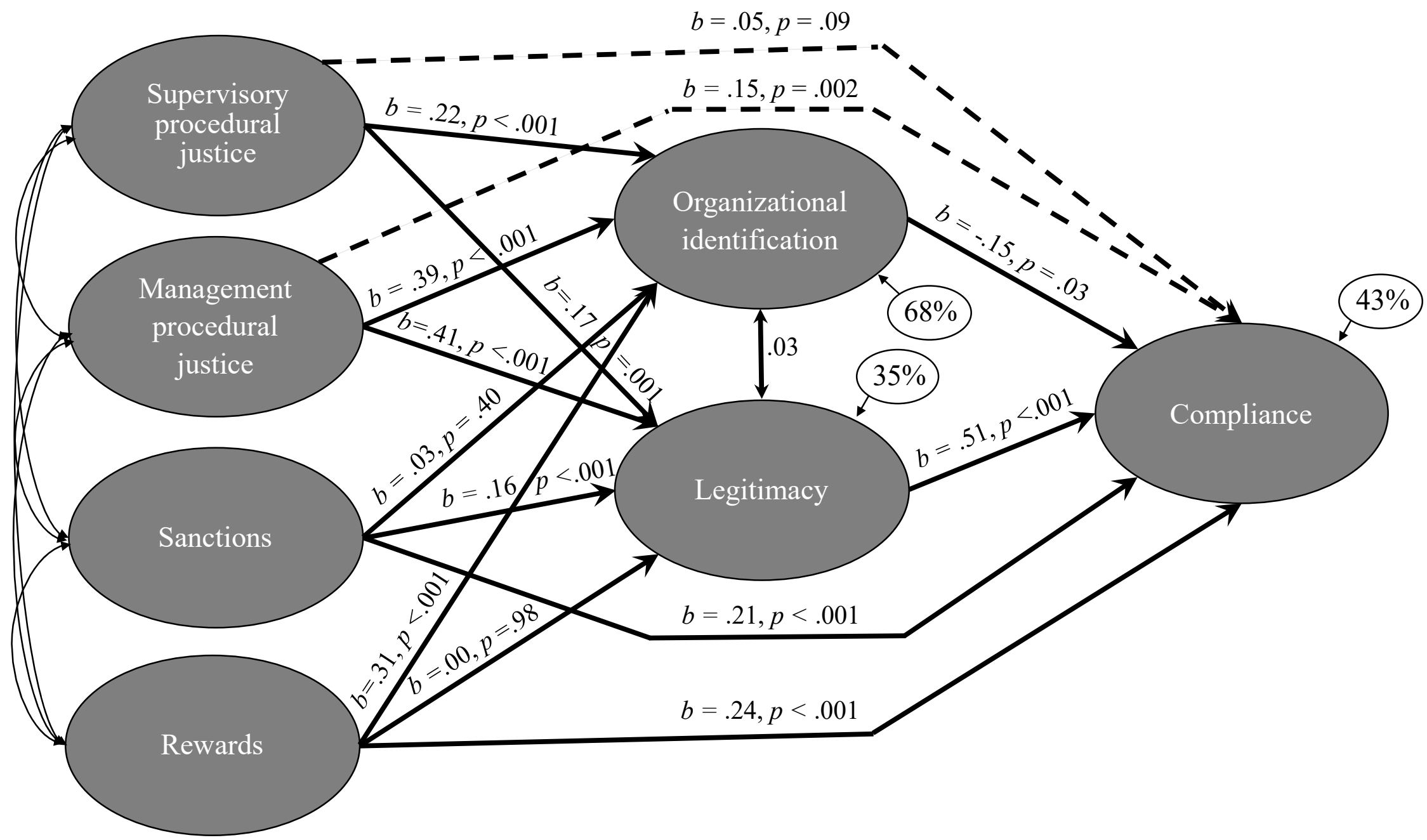

Figure 2. Study 1 SEM for compliance with categorical indicators using Mplus 7.2 and gender and age as controls.

Exact fit statistics: $\chi^{2}(471)=1732.01, p<.001$. Approximate fit statistics: CFI 0.96; TLI 0.96; RMSEA $=0.07,90 \%$ CI [0.06, 0.07].

Standardized regression coefficients provided. 


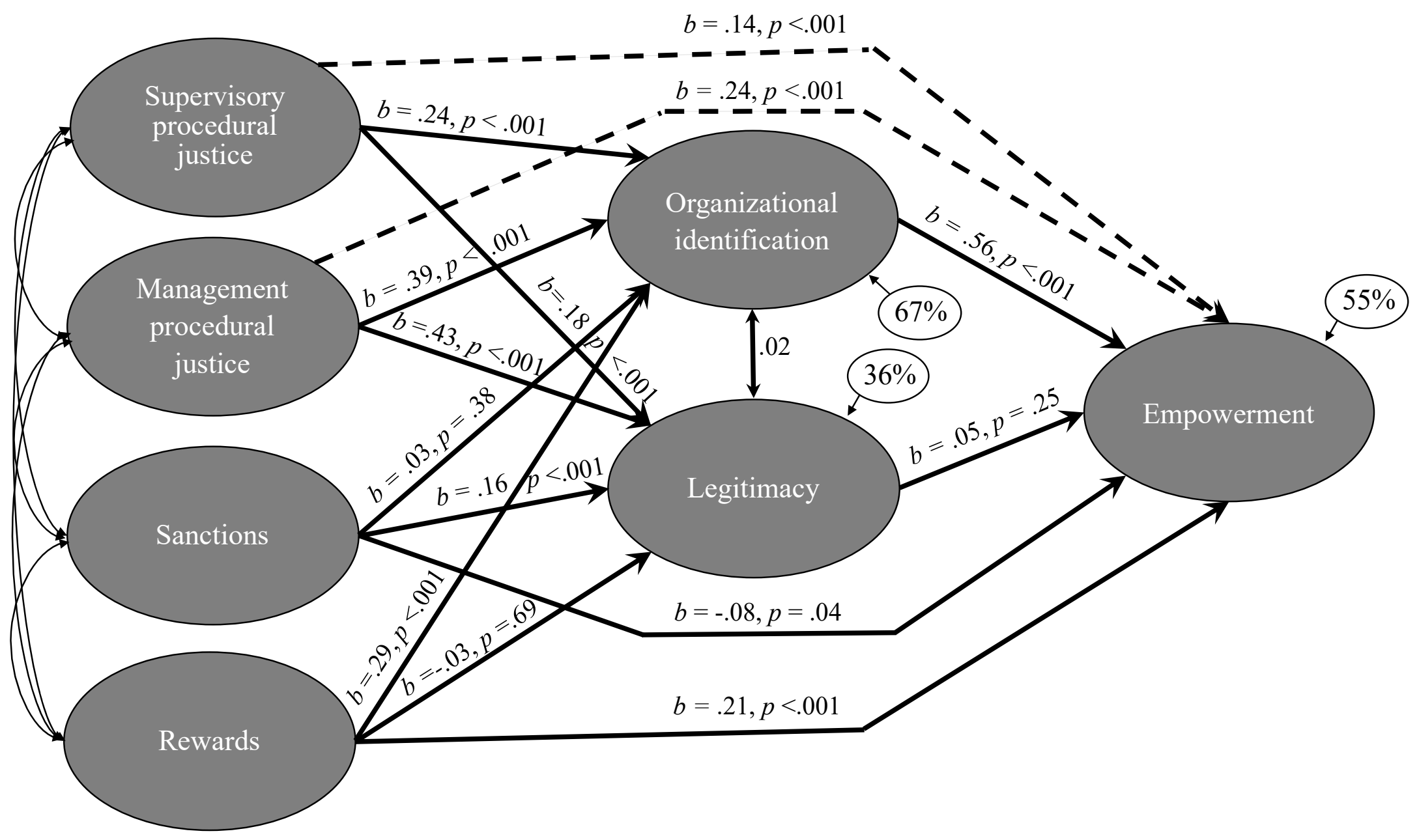

Figure 3. Study 1 SEM for empowerment with categorical indicators using Mplus 7.2 and gender and age as controls.

Exact fit statistics: $\chi^{2}(410)=1519.99, p<.001$. Approximate fit statistics: CFI 0.97; TLI 0.96; RMSEA $=0.07,90 \%$ CI [0.06, 0.07]. Standardized regression coefficients provided. 


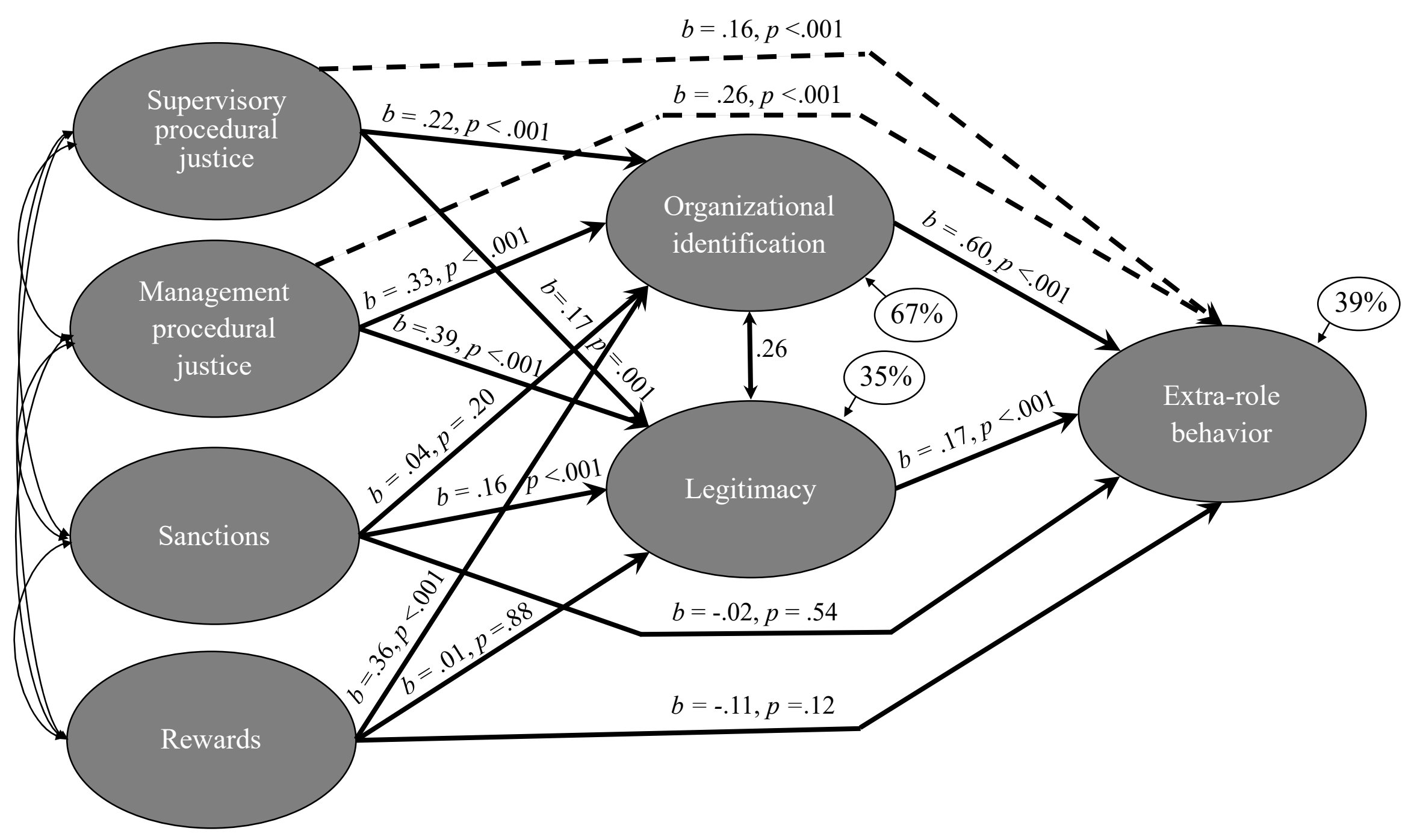

Figure 4. Study 1 SEM for extra-role behavior with categorical indicators using Mplus 7.2 and gender and age as controls.

Exact fit statistics: $\chi^{2}(381)=1504.83, p<.001$. Approximate fit statistics: CFI 0.97; TLI 0.96; RMSEA $=0.07,90 \%$ CI [0.07, 0.07].

Standardized regression coefficients provided. 


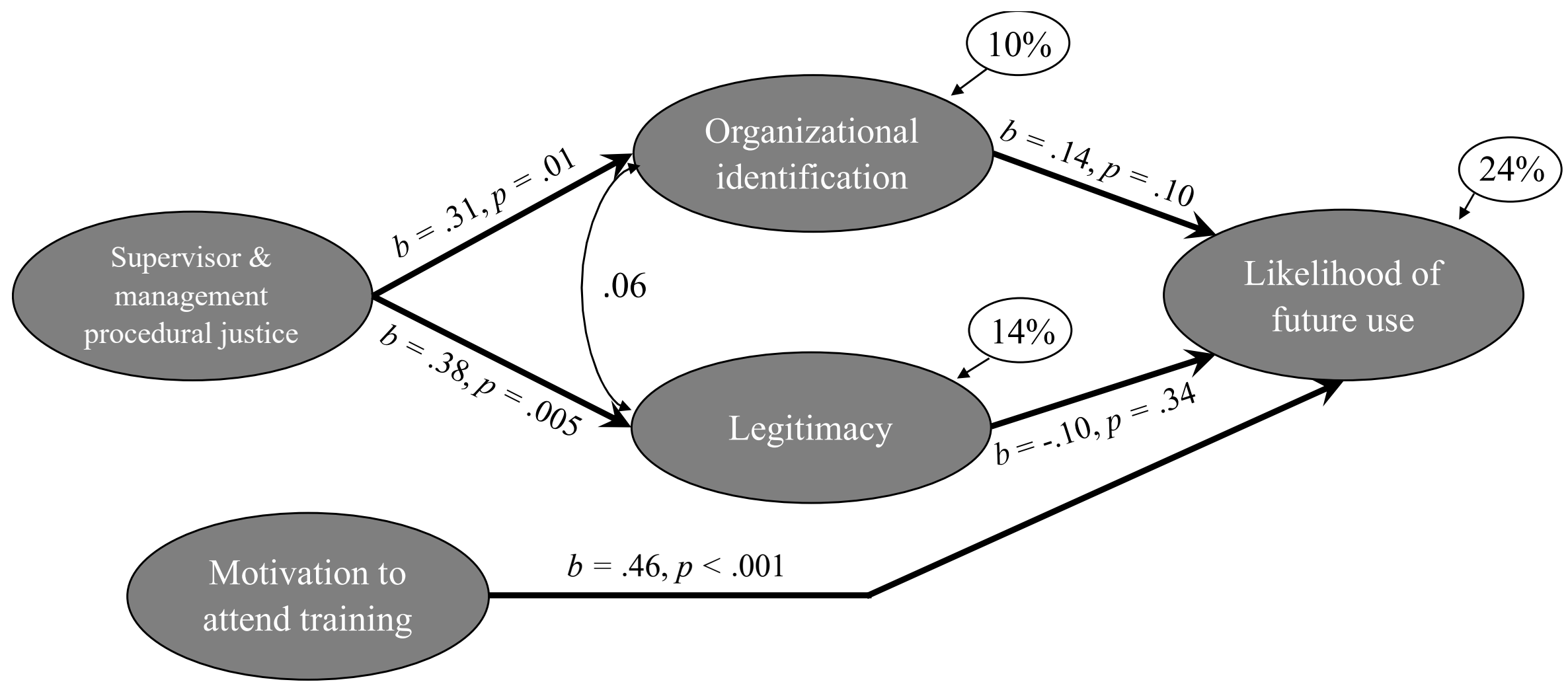

Figure 5. Study 2 path analysis for likelihood of future use using MPlus 7.2.

Exact fit statistics: $\chi^{2}(3)=1.03, p=.79$.

Approximate fit statistics: CFI 1.00; TLI 1.23; RMSEA $<.001,90 \%$ CI $[0.00,0.13]$.

Standardized regression coefficients provided. 


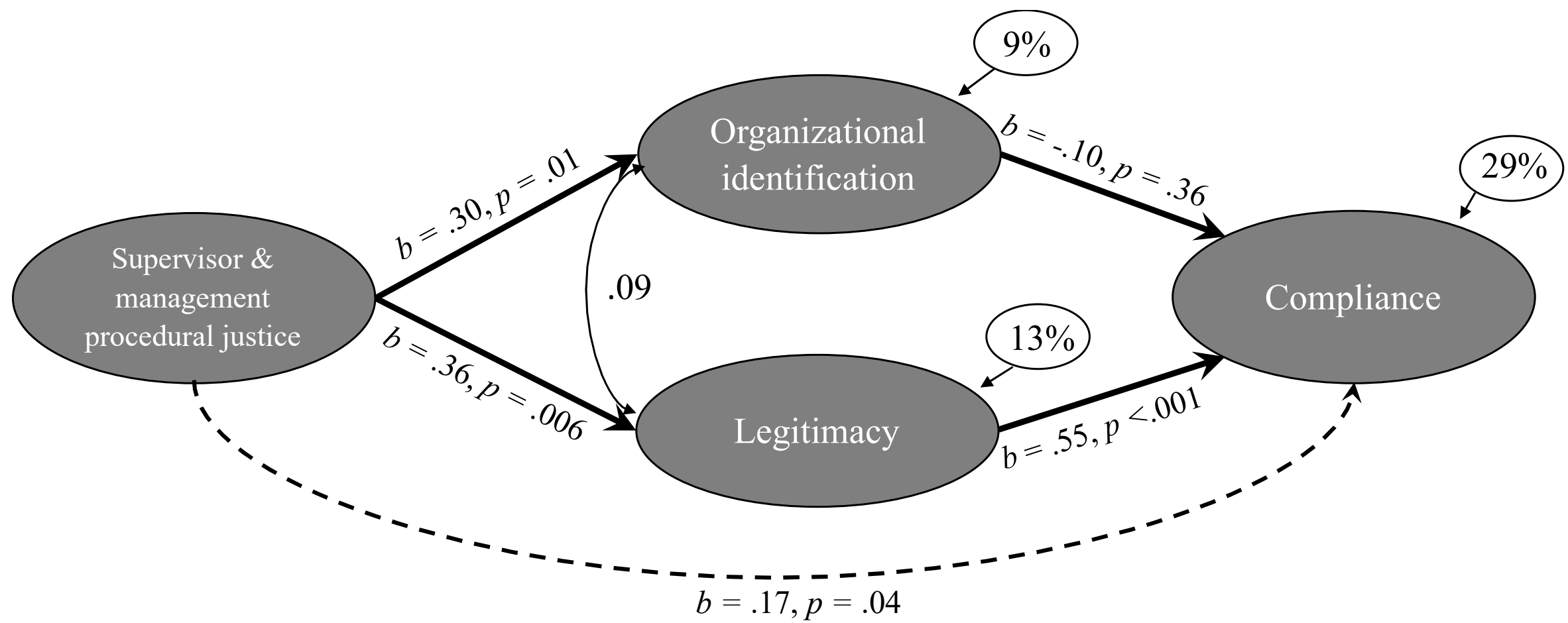

Figure 6. Study 2 path analysis for compliance using MPlus 7.2.

Exact fit statistics: $\chi^{2}(1)=0.52, p=.47$.

Approximate fit statistics: CFI 1.00; TLI 1.10; RMSEA $<.001,95 \%$ CI [0.00, 0.28].

Standardized regression coefficients provided. 


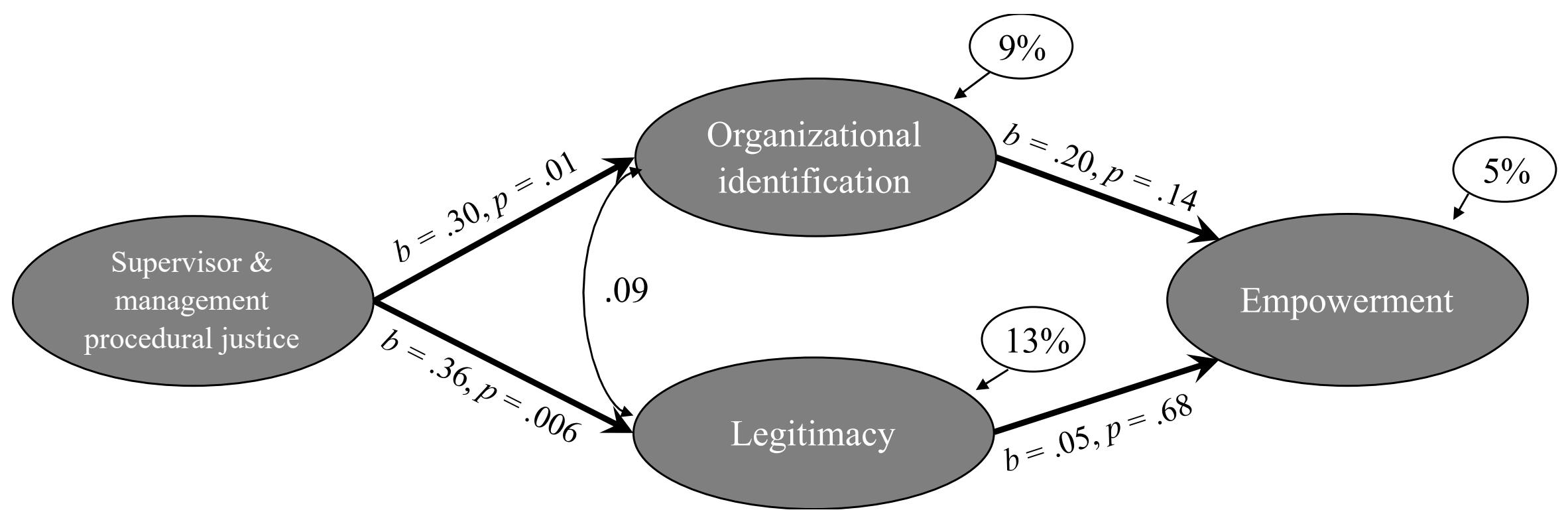

Figure 7. Study 2 path analysis for empowerment using MPlus 7.2.

Exact fit statistics: $\chi^{2}(1)=0.552, p=.46$.

Approximate fit statistics: CFI 1.00; TLI 1.21. RMSEA < .001, 90\% CI [0.00, 0.28].

Standardized regression coefficients provided. 


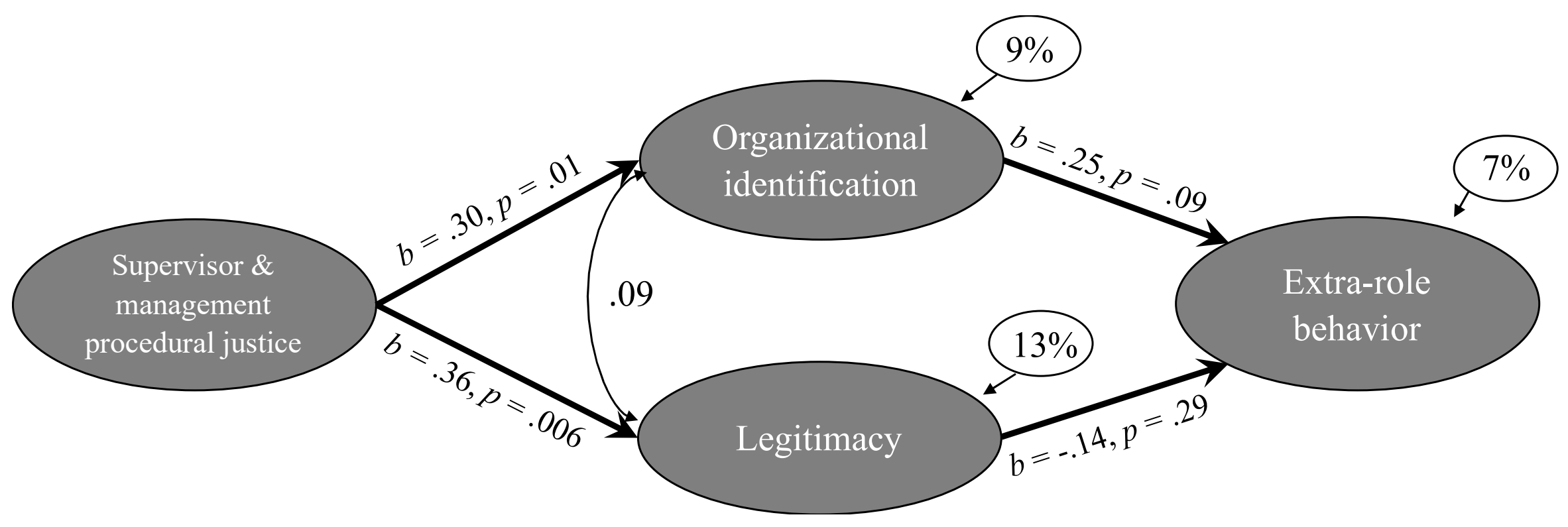

Figure 8. Study 2 path analysis for extra-role behavior using MPlus 7.2.

Exact fit statistics: $\chi^{2}(1)=0.51, p=.47$.

Approximate fit statistics: CFI 1.00; TLI 1.25; RMSEA $<.001,90 \%$ CI $[0.00,0.28]$.

Standardized regression coefficients provided. 
Table 1

Fit statistics for a series of fitted CFA models [left and middle layer constructs]

\begin{tabular}{|c|c|c|c|c|c|c|c|c|}
\hline Model & & Chi-Square & df & $p$ & RMSEA & $\begin{array}{l}\text { RMSEA 90\% } \\
\text { CI }\end{array}$ & CFI & TLI \\
\hline M1 & Six factors & 1453 & 260 & $<.001$ & 0.08 & $0.08-0.09$ & 0.96 & 0.96 \\
\hline М2 & $\begin{array}{l}\text { Five factors (combining the two } \\
\text { procedural justice constructs) }\end{array}$ & 2899 & 265 & $<.001$ & 0.12 & $0.12-0.13$ & 0.92 & 0.91 \\
\hline M3 & $\begin{array}{l}\text { Five factors (combining supervisor } \\
\text { procedural justice and identification) }\end{array}$ & 3023 & 265 & $<.001$ & 0.12 & $0.12-0.13$ & 0.92 & 0.90 \\
\hline M4 & $\begin{array}{l}\text { Five factors (combining management } \\
\text { procedural justice and identification) }\end{array}$ & 2248 & 265 & $<.001$ & 0.11 & $0.10-0.11$ & 0.94 & 0.93 \\
\hline M5 & $\begin{array}{l}\text { Five factors (combining legitimacy } \\
\text { and identification) }\end{array}$ & 2548 & 265 & $<.001$ & 0.11 & $0.11-0.12$ & 0.93 & 0.92 \\
\hline M6 & $\begin{array}{l}\text { Five factors (combining supervisor } \\
\text { procedural justice and sanction) }\end{array}$ & 4312 & 265 & $<.001$ & 0.15 & $0.15-0.15$ & 0.88 & 0.86 \\
\hline M7 & $\begin{array}{l}\text { Five factors (combining management } \\
\text { procedural justice and sanction) }\end{array}$ & 4536 & 265 & $<.001$ & 0.15 & $0.15-0.16$ & 0.87 & 0.85 \\
\hline
\end{tabular}


Table 2

Correlations between six latent constructs

\begin{tabular}{lccccc} 
& 1 & 2 & 3 & 4 & 5 \\
1. Supervisory procedural justice & - & & & & \\
2. Management procedural justice & .57 & - & & & \\
3. Sanctions & .16 & .29 & - & & \\
4. Rewards & .66 & .76 & .14 & - & \\
5. Organizational identification & .64 & .76 & .22 & .75 & - \\
6. Legitimacy & .43 & .56 & .32 & .43 & .46 \\
\hline
\end{tabular}

Note. All ps $<.001$ 
Table 3

Ranges of factor loadings and $R^{2}$ values by construct

\begin{tabular}{|c|c|c|c|c|}
\hline \multirow[b]{2}{*}{ Construct } & \multicolumn{2}{|c|}{ Factor loadings } & \multicolumn{2}{|c|}{$R^{2}$} \\
\hline & Lowest & Highest & Lowest & Highest \\
\hline Supervisory procedural justice & 0.87 & 0.93 & 0.75 & 0.87 \\
\hline Management procedural justice & 0.77 & 0.92 & 0.59 & 0.85 \\
\hline Sanctions & 0.84 & 0.90 & 0.71 & 0.80 \\
\hline Rewards & 0.59 & 0.69 & 0.35 & 0.48 \\
\hline Organizational identification & 0.59 & 0.95 & 0.35 & 0.50 \\
\hline Legitimacy & 0.74 & 0.81 & 0.75 & 0.90 \\
\hline
\end{tabular}


Table 4

Results for SEM with compliance as outcome (Figure 2)

\begin{tabular}{lccccccccccc}
\hline \multicolumn{1}{c}{ Path } & $\begin{array}{c}\text { Unstandardized } \\
\text { coefficient }\end{array}$ & $\begin{array}{c}\text { Lower } \\
95 \% \text { CI }\end{array}$ & $\begin{array}{c}\text { Upper } \\
95 \% \text { CI }\end{array}$ & S.E. & $\begin{array}{c}\text { Standardized } \\
\text { coefficient }\end{array}$ & $\begin{array}{c}\text { Lower } \\
95 \% \text { CI }\end{array}$ & $\begin{array}{c}\text { Upper } \\
95 \% \text { CI }\end{array}$ & S.E. & $p$-value \\
\hline Direct & & & & & & & & & & \\
Supervisory PJ -> Identification & 0.15 & 0.12 & 0.19 & 0.02 & 0.22 & 0.17 & 0.27 & 0.03 & $<.001$ \\
Management PJ -> Identification & 0.31 & 0.26 & 0.36 & 0.03 & 0.39 & 0.33 & 0.46 & 0.04 & $<.001$ \\
Sanctions -> Identification & 0.02 & -0.02 & 0.05 & 0.02 & 0.03 & -0.02 & 0.07 & 0.03 & .40 \\
Rewards -> Identification & 0.27 & 0.19 & 0.34 & 0.05 & 0.31 & 0.23 & 0.39 & 0.05 & $<.001$ \\
Supervisory PJ -> Legitimacy & 0.16 & 0.08 & 0.24 & 0.05 & 0.17 & 0.08 & 0.25 & 0.05 & .001 \\
Management PJ -> Legitimacy & 0.44 & 0.32 & 0.57 & 0.08 & 0.41 & 0.29 & 0.52 & 0.07 & $<.001$ \\
Sanctions -> Legitimacy & 0.16 & 0.09 & 0.23 & 0.04 & 0.16 & 0.09 & 0.23 & 0.04 & $<.001$ \\
Rewards -> Legitimacy & 0.00 & -0.16 & 0.16 & 0.10 & 0.00 & -0.13 & 0.14 & 0.08 & .98 \\
Identification -> Compliance & -0.17 & -0.30 & -0.04 & 0.08 & -0.15 & -0.25 & -0.04 & 0.07 & .03 \\
Legitimacy -> Compliance & 0.43 & 0.36 & 0.50 & 0.05 & 0.51 & 0.43 & 0.58 & 0.04 & $<.001$ \\
Sanctions -> Compliance & 0.18 & 0.12 & 0.24 & 0.04 & 0.21 & 0.14 & 0.28 & 0.04 & $<.001$ \\
Rewards -> Compliance & 0.24 & 0.13 & 0.35 & 0.07 & 0.24 & 0.13 & 0.34 & 0.07 & $<.001$ \\
Indirect & & & & & & & & \\
Supervisory PJ -> Compliance & 0.04 & 0.00 & 0.08 & 0.03 & 0.05 & 0.00 & 0.10 & 0.03 \\
$\quad$ Via identification & -0.02 & -0.05 & -0.01 & 0.01 & -0.03 & -0.06 & -0.01 & 0.02 & .09 \\
Via legitimacy & 0.07 & 0.03 & 0.11 & 0.02 & 0.08 & 0.04 & 0.13 & 0.03 & .002 \\
Management PJ -> Compliance & 0.14 & 0.07 & 0.21 & 0.04 & 0.15 & 0.07 & 0.23 & 0.05 & .002 \\
Via identification & -0.05 & -0.09 & -0.01 & 0.02 & -0.06 & -0.10 & -0.02 & 0.03 \\
Via legitimacy & 0.19 & 0.12 & 0.25 & 0.04 & 0.21 & 0.14 & 0.28 & 0.04 & $<.03$ \\
\hline
\end{tabular}

Note. Gender and age were not significant predictors 
Table 5

Results for SEM with empowerment as outcome (Figure 3)

\begin{tabular}{lcccccccccc}
\hline \multicolumn{1}{c}{ Path } & $\begin{array}{c}\text { Unstandardized } \\
\text { coefficient }\end{array}$ & $\begin{array}{c}\text { Lower } \\
95 \% \text { CI }\end{array}$ & $\begin{array}{c}\text { Upper } \\
95 \% \text { CI }\end{array}$ & S.E. & $\begin{array}{c}\text { Standardized } \\
\text { coefficient }\end{array}$ & $\begin{array}{c}\text { Lower } \\
95 \% \text { CI }\end{array}$ & $\begin{array}{c}\text { Upper } \\
95 \% \text { CI }\end{array}$ & S.E. & $p$-value \\
\hline Direct & & & & & & & & & & \\
Supervisory PJ -> Identification & 0.17 & 0.13 & 0.21 & 0.02 & 0.24 & 0.19 & 0.29 & 0.03 & $<.001$ \\
Management PJ -> Identification & 0.31 & 0.26 & 0.36 & 0.03 & 0.39 & 0.33 & 0.45 & 0.04 & $<.001$ \\
Sanctions -> Identification & 0.02 & -0.02 & 0.05 & 0.02 & 0.03 & -0.02 & 0.07 & 0.03 & .38 \\
Rewards -> Identification & 0.25 & 0.17 & 0.33 & 0.05 & 0.29 & 0.20 & 0.37 & 0.05 & $<.001$ \\
Supervisory PJ -> Legitimacy & 0.17 & 0.09 & 0.25 & 0.05 & 0.18 & 0.10 & 0.26 & 0.05 & $<.001$ \\
Management PJ -> Legitimacy & 0.46 & 0.34 & 0.59 & 0.08 & 0.43 & 0.32 & 0.55 & 0.07 & $<.001$ \\
Sanctions -> Legitimacy & 0.15 & 0.08 & 0.22 & 0.04 & 0.16 & 0.09 & 0.22 & 0.04 & $<.001$ \\
Rewards -> Legitimacy & -0.04 & -0.20 & 0.12 & 0.10 & -0.03 & -0.17 & 0.10 & 0.08 & .69 \\
Identification -> Empowerment & 0.74 & 0.61 & 0.88 & 0.08 & 0.56 & 0.47 & 0.65 & 0.06 & $<.001$ \\
Legitimacy -> Empowerment & 0.05 & -0.02 & 0.12 & 0.04 & 0.05 & -0.02 & 0.12 & 0.04 & .25 \\
Sanctions -> Empowerment & -0.08 & -0.13 & -0.02 & 0.04 & -0.08 & -0.14 & -0.02 & 0.04 & .04 \\
Rewards -> Empowerment & 0.24 & 0.12 & 0.36 & 0.08 & 0.21 & 0.10 & 0.31 & 0.06 & .001 \\
Indirect & & & & & & & & \\
Supervisory PJ -> Empowerment & 0.13 & 0.09 & 0.17 & 0.02 & 0.14 & 0.10 & 0.18 & 0.03 & $<.001$ \\
$\quad$ Via identification & 0.12 & 0.09 & 0.16 & 0.02 & 0.14 & 0.09 & 0.18 & 0.02 & $<.001$ \\
Via legitimacy & 0.01 & -0.01 & 0.02 & 0.01 & 0.01 & -0.01 & 0.02 & 0.01 & .30 \\
Management PJ -> Empowerment & 0.25 & 0.19 & 0.32 & 0.04 & 0.24 & 0.18 & 0.30 & 0.04 & $<.001$ \\
Via identification & 0.23 & 0.17 & 0.29 & 0.03 & 0.22 & 0.17 & 0.27 & 0.03 & $<.001$ \\
Via legitimacy & 0.02 & -0.01 & 0.06 & 0.02 & 0.02 & -0.01 & 0.05 & 0.02 & .26 \\
\hline
\end{tabular}

Note. Gender and age were not significant predictors 
Table 6

Results for SEM with extra-role behavior as outcome (Figure 4)

\begin{tabular}{|c|c|c|c|c|c|c|c|c|c|}
\hline Path & $\begin{array}{l}\text { Unstandardized } \\
\text { coefficient }\end{array}$ & $\begin{array}{c}\text { Lower } \\
95 \% \\
\text { CI }\end{array}$ & $\begin{array}{l}\text { Upper } \\
95 \% \text { CI }\end{array}$ & S.E. & $\begin{array}{l}\text { Standardized } \\
\text { coefficient }\end{array}$ & $\begin{array}{l}\text { Lower } \\
95 \% \text { CI }\end{array}$ & $\begin{array}{l}\text { Upper } \\
95 \% \text { CI }\end{array}$ & S.E. & $p$-value \\
\hline \multicolumn{10}{|l|}{ Direct } \\
\hline Supervisory PJ -> Identification & 0.16 & 0.12 & 0.20 & 0.02 & 0.22 & 0.16 & 0.27 & 0.03 & $<.001$ \\
\hline Management PJ -> Identification & 0.27 & 0.21 & 0.33 & 0.04 & 0.33 & 0.26 & 0.40 & 0.04 & $<.001$ \\
\hline Sanctions -> Identification & 0.03 & -0.01 & 0.06 & 0.02 & 0.04 & -0.01 & 0.09 & 0.03 & .20 \\
\hline Rewards -> Identification & 0.32 & 0.23 & 0.41 & 0.05 & 0.36 & 0.27 & 0.45 & 0.06 & $<.001$ \\
\hline Supervisory PJ -> Legitimacy & 0.16 & 0.08 & 0.24 & 0.05 & 0.17 & 0.09 & 0.25 & 0.05 & .001 \\
\hline Management PJ -> Legitimacy & 0.41 & 0.28 & 0.55 & 0.08 & 0.39 & 0.26 & 0.51 & 0.08 & $<.001$ \\
\hline Sanctions -> Legitimacy & 0.16 & 0.09 & 0.22 & 0.04 & 0.16 & 0.09 & 0.23 & 0.04 & $<.001$ \\
\hline Rewards -> Legitimacy & 0.02 & -0.15 & 0.18 & 0.10 & 0.01 & -0.13 & 0.16 & 0.09 & .88 \\
\hline Identification $->$ Extra-role behavior & 0.71 & 0.58 & 0.85 & 0.08 & 0.60 & 0.50 & 0.70 & 0.06 & $<.001$ \\
\hline Legitimacy -> Extra-role behavior & 0.15 & 0.08 & 0.22 & 0.04 & 0.17 & 0.09 & 0.24 & 0.04 & $<.001$ \\
\hline Sanctions -> Extra-role behavior & -0.02 & -0.08 & 0.04 & 0.04 & -0.02 & -0.09 & 0.04 & 0.04 & .54 \\
\hline Rewards -> Extra-role behavior & -0.12 & -0.24 & 0.01 & 0.08 & -0.11 & -0.23 & 0.01 & 0.07 & .12 \\
\hline \multicolumn{10}{|l|}{ Indirect } \\
\hline Supervisory PJ -> Extra-role behavior & 0.14 & 0.10 & 0.17 & 0.02 & 0.16 & 0.12 & 0.20 & 0.02 & $<.001$ \\
\hline Via identification & 0.11 & 0.08 & 0.14 & 0.02 & 0.13 & 0.09 & 0.17 & 0.02 & $<.001$ \\
\hline Via legitimacy & 0.02 & 0.01 & 0.04 & 0.01 & 0.03 & 0.01 & 0.05 & 0.01 & .02 \\
\hline Management PJ _> Extra-role behavior & 0.25 & 0.20 & 0.31 & 0.04 & 0.26 & 0.21 & 0.32 & 0.04 & $<.001$ \\
\hline Via identification & 0.19 & 0.14 & 0.24 & 0.03 & 0.2 & 0.15 & 0.25 & 0.03 & $<.001$ \\
\hline Via legitimacy & 0.06 & 0.03 & 0.09 & 0.02 & 0.06 & 0.03 & 0.10 & 0.02 & .001 \\
\hline
\end{tabular}

Note. Gender and age were not significant predictors 
Table 7

Results for SEM with likelihood of future use as outcome (Figure 5)

\begin{tabular}{|c|c|c|c|c|c|c|c|c|c|}
\hline Path & $\begin{array}{l}\text { Unstandardized } \\
\text { coefficient }\end{array}$ & $\begin{array}{c}\text { Lower } \\
95 \% \\
\text { CI }\end{array}$ & $\begin{array}{c}\text { Upper } \\
95 \% \\
\text { CI }\end{array}$ & S.E. & $\begin{array}{l}\text { Standardized } \\
\text { coefficient }\end{array}$ & $\begin{array}{l}\text { Lower } \\
95 \% \text { CI }\end{array}$ & $\begin{array}{l}\text { Upper } \\
95 \% \text { CI }\end{array}$ & S.E. & $p$-value \\
\hline \multicolumn{10}{|l|}{ Direct } \\
\hline Procedural Justice -> Identification & 0.19 & 0.06 & 0.31 & 0.08 & 0.31 & 0.13 & 0.49 & 0.11 & .01 \\
\hline Procedural Justice -> Legitimacy & 0.55 & 0.23 & 0.88 & 0.20 & 0.38 & 0.18 & 0.57 & 0.12 & .005 \\
\hline Identification -> Likelihood of future use & 0.12 & 0.00 & 0.25 & 0.07 & 0.14 & -0.03 & 0.32 & 0.11 & .10 \\
\hline Legitimacy -> Likelihood of future use & -0.04 & -0.10 & 0.03 & 0.04 & -0.10 & -0.29 & 0.08 & 0.11 & .34 \\
\hline Motivation -> Likelihood of future use & 0.28 & 0.16 & 0.40 & 0.07 & 0.46 & 0.31 & 0.62 & 0.09 & $<.001$ \\
\hline \multicolumn{10}{|l|}{ Indirect } \\
\hline Procedural Justice -> Likelihood of future use & 0.00 & -0.04 & 0.05 & 0.03 & 0.01 & -0.08 & 0.09 & 0.01 & .93 \\
\hline Via identification & 0.02 & -0.01 & 0.05 & 0.02 & 0.04 & -0.01 & 0.10 & 0.03 & .19 \\
\hline Via legitimacy & -0.02 & -0.06 & 0.02 & 0.02 & -0.04 & -0.11 & 0.03 & 0.04 & .35 \\
\hline
\end{tabular}


Table 8

Results for SEM with compliance as outcome (Figure 6)

\begin{tabular}{lccccccccc}
\hline \multicolumn{1}{c}{ Path } & $\begin{array}{c}\text { Unstandardized } \\
\text { coefficient }\end{array}$ & $\begin{array}{c}\text { Lower } \\
95 \% \text { CI }\end{array}$ & $\begin{array}{c}\text { Upper } \\
95 \% \text { CI }\end{array}$ & S.E. & $\begin{array}{c}\text { Standardized } \\
\text { coefficient }\end{array}$ & $\begin{array}{c}\text { Lower } \\
95 \% \text { CI }\end{array}$ & $\begin{array}{c}\text { Upper } \\
95 \% \text { CI }\end{array}$ & S.E. & $p$-value \\
\hline Direct & & & & & & & & & \\
Procedural Justice -> Identification & 0.18 & 0.07 & 0.30 & 0.07 & 0.30 & 0.12 & 0.48 & 0.11 & .01 \\
Procedural Justice -> Legitimacy & 0.53 & 0.22 & 0.84 & 0.19 & 0.36 & 0.16 & 0.55 & 0.12 & .006 \\
Identification -> Compliance & -0.15 & -0.42 & 0.13 & 0.16 & -0.10 & -0.27 & 0.09 & 0.11 & .36 \\
Legitimacy -> Compliance & 0.35 & 0.23 & 0.46 & 0.07 & 0.55 & 0.39 & 0.70 & 0.10 & $<.001$ \\
Indirect & & & & & & & & \\
Procedural Justice -> Compliance & 0.16 & 3.00 & 0.29 & 0.17 & 0.17 & 0.03 & 0.30 & 0.08 & .04 \\
$\quad$ Via identification & -0.03 & -0.08 & 0.03 & -0.03 & -0.03 & -0.08 & 0.03 & 0.03 & .41 \\
$\quad$ Via legitimacy & 0.18 & 0.06 & 0.31 & 0.20 & 0.20 & 0.07 & 0.32 & 0.08 & .01 \\
\hline
\end{tabular}


Table 9

Results for SEM with empowerment as outcome (Figure 7)

\begin{tabular}{lccccccccc}
\multicolumn{1}{c}{ Path } & $\begin{array}{c}\text { Unstandardized } \\
\text { coefficient }\end{array}$ & $\begin{array}{c}\text { Lower } \\
95 \% \text { CI }\end{array}$ & $\begin{array}{c}\text { Upper } \\
95 \% \text { CI }\end{array}$ & S.E. & $\begin{array}{c}\text { Standardized } \\
\text { coefficient }\end{array}$ & $\begin{array}{c}\text { Lower } \\
95 \% \text { CI }\end{array}$ & $\begin{array}{c}\text { Upper } \\
95 \% \text { CI }\end{array}$ & S.E. & $p$-value \\
\hline Direct & & & & & & & & & \\
Procedural Justice -> Identification & 0.18 & 0.07 & 0.30 & 0.07 & 0.30 & 0.12 & 0.48 & 0.11 & .01 \\
Procedural Justice -> Legitimacy & 0.53 & 0.22 & 0.84 & 0.19 & 0.36 & 0.16 & 0.55 & 0.12 & .006 \\
Identification -> Empowerment & 0.22 & -0.02 & 0.45 & 0.15 & 0.20 & -0.01 & 0.40 & 0.13 & .14 \\
Legitimacy -> Empowerment & 0.02 & -0.07 & 0.12 & 0.06 & 0.05 & -0.16 & 0.27 & 0.13 & .68 \\
Indirect & & & & & & & & \\
Procedural Justice -> Empowerment & 0.05 & -0.01 & 0.12 & 0.04 & 0.08 & -0.02 & 0.17 & 0.06 & .17 \\
$\quad$ Via identification & 0.04 & -0.01 & 0.09 & 0.04 & 0.06 & -0.01 & 0.13 & 0.05 & .27 \\
$\quad$ Via legitimacy & 0.01 & -0.04 & 0.07 & 0.03 & 0.02 & -0.06 & 0.10 & 0.05 & .69 \\
\hline
\end{tabular}


Table 10

Results for SEM with extra-role behavior as outcome (Figure 8)

\begin{tabular}{lccccccccc}
\hline \multicolumn{1}{c}{ Path } & $\begin{array}{c}\text { Unstandardized } \\
\text { coefficient }\end{array}$ & $\begin{array}{c}\text { Lower } \\
95 \% \text { CI }\end{array}$ & $\begin{array}{c}\text { Upper } \\
95 \% \text { CI }\end{array}$ & S.E. & $\begin{array}{c}\text { Standardized } \\
\text { coefficient }\end{array}$ & $\begin{array}{c}\text { Lower } \\
95 \% \text { CI }\end{array}$ & $\begin{array}{c}\text { Upper } \\
95 \% \text { CI }\end{array}$ & S.E. & $p$-value \\
\hline Direct & & & & & & & & & \\
Procedural Justice -> Identification & 0.18 & 0.07 & 0.30 & 0.07 & 0.30 & 0.12 & 0.48 & 0.11 & .01 \\
Procedural Justice -> Legitimacy & 0.53 & 0.22 & 0.84 & 0.19 & 0.36 & 0.16 & 0.55 & 0.12 & .006 \\
Identification -> Extra-role & 0.26 & 0.05 & 0.47 & 0.15 & 0.25 & 0.05 & 0.45 & 0.12 & .09 \\
Legitimacy -> Extra-role & -0.06 & -0.15 & 0.03 & 0.06 & -0.14 & -0.35 & 0.07 & 0.13 & .29 \\
Indirect & & & & & & & & \\
Procedural Justice -> Extra-role & 0.02 & -0.05 & 0.08 & 0.04 & 0.02 & -0.08 & 0.13 & 0.06 & .74 \\
$\quad$ Via identification & 0.05 & 0.00 & 0.09 & 0.04 & 0.07 & 0.00 & 0.15 & 0.05 & .20 \\
$\quad$ Via legitimacy & -0.03 & -0.08 & 0.02 & 0.03 & -0.05 & -0.13 & 0.03 & 0.05 & .35 \\
\hline
\end{tabular}


Table 11

Results of the follow up univariate tests (ANOVAs) and marginal means for the MANOVA comparing responses from Study 1 and Study 2

\begin{tabular}{lcccc}
\hline & $\begin{array}{c}\text { Study 1 } \\
\text { Means (SD) }\end{array}$ & $\begin{array}{c}\text { Study 2 } \\
\text { Means (SD) }\end{array}$ & $F$-test & $\begin{array}{c}\text { Effect sizes } \\
95 \% \text { CIs }\end{array}$ \\
\hline $\begin{array}{l}\text { Supervisory procedural } \\
\text { justice }\end{array}$ & $4.92(1.75)$ & $5.44(1.32)$ & $F(1,692)=4.70, p=.03$ & $d=0.30,[0.07,0.54]$ \\
$\begin{array}{l}\text { Management procedural } \\
\text { justice }\end{array}$ & $3.64(1.81)$ & $4.59(1.49)$ & $F(1,692)=7.45, p<.001$ & $d=0.53,[0.28,0.78]$ \\
Sanctions & $5.42(1.55)$ & $5.78(1.29)$ & $F(1,692)=3.12, p=.08$ & $d=0.24,[-0.03,0.50]$ \\
Rewards & $4.29(1.78)$ & $5.47(1.21)$ & $F(1,692)=25.60, p<.001$ & $d=0.68,[0.41,0.95]$ \\
Organizational identification & $5.26(1.29)$ & $6.09(0.72)$ & $F(1,692)=21.53, p<.001$ & $d=0.66,[0.42,0.91]$ \\
Legitimacy & $4.22(1.64)$ & $3.93(1.74)$ & $F(1,692)=1.69, p=.19$ & $d=-0.18,[-0.44,0.09]$ \\
Compliance & $5.19(1.03)$ & $5.01(1.11)$ & $F(1,692)=1.61, p=.20$ & $d=-0.17,[-0.44,0.09]$ \\
Empowerment & $5.37(1.72)$ & $6.27(0.81)$ & $F(1,692)=15.87, p<.001$ & $d=0.54,[0.27,0.81]$ \\
Extra-role behavior & $5.75(1.32)$ & $6.23(0.75)$ & $F(1,692)=7.45, p=.006$ & $d=0.37,[0.11,0.64]$ \\
\hline
\end{tabular}

